\title{
FROM JAPAN TO AFGHANISTAN: THE U.S.JAPAN JOINT SECURITY RELATIONSHIP, THE WAR ON TERROR, AND THE IGNOMINIOUS END OF THE PACIFIST STATE?
}

\author{
EDWARD J.L. SOUTHGATE ${ }^{\dagger}$
}

\section{INTRODUCTION}

On November 9, 2001, three warships of the Japan Maritime SelfDefense Forces (JMSDF or Kaigun) left Sasebo naval base for Diego Garcia in the Indian Ocean in support of Operation Enduring Freedom.' This dispatch commenced the first combat theater operations of the Japanese navy abroad since the end of hostilities in 1945 and followed the overwhelming Diet approval, two weeks earlier, of the Anti-Terrorism Special Measures Law. ${ }^{2}$ On its face the law grants the

${ }^{1}$ B.A. 2000, University of Pennsylvania; M.A. 2000, University of Pennsylvania; M.A. 2001, Columbia University; J.D. Candidate 2004, University of Pennsylvania. I would like to take this opportunity to thank the many people without whom this Comment may not have been finished, let alone published. First and foremost, to borrow a phrase from Michael Bacchus, even the most rococo of constructions could not appropriately reflect the love I feel toward my family. I owe a deep debt of gratitude to the Associate Editors for their brutally honest and helpful critiques. In addition, thanks to the Comments Office for shepherding this Comment through the publication process. I would also like to thank my faculty mentor, Eric Feldman, for providing useful suggestions during the course of my research and for reading the Comment in draft form. Thanks are also due to my compatriots Rick Horvath, Eric Marr, and Chris Williamson for their feedback on the draft copy. Finally, I would like to thank Mishuku Matsuda for her tireless support of this project and her limitless patience while I was writing it. Any errors of fact, logic, or admission of course remain entirely with the author. Please note that all Western names are stated in the Western fashion with the given name preceding the family name. Japanese names, except as signatures to English language sources in citation (where they appear as in the cited source), follow the East Asian fashion and are given in the reverse order, with the family name preceding the given name.

I The three ships dispatched were the destroyer Kurama, with a displacement of 5200 tons, the destroyer Kirisame, with a displacement of 4550 tons, and the supply ship Haman, with a displacement of 8100 tons. In total, these three ships carried some seven hundred members of the JMSDF. Japanese Warships Set Sail, CNN.COM (Nov. 9, 2001), at http://www.cnn.com/2001/WORLD/asiapcf/east/11/08/ret.japan .warships/.

${ }^{2}$ See Foreign Press Center, Diet Passes Antiterrorism Special Measures Law, http://www.fpcj.jp/e/shiryo/jb/0145.html (Nov. 9, 2001) (noting that the bill was enacted after "just three weeks of speedy deliberations in the Diet" by majority vote and 
with the support of the ruling coalition consisting of the Liberal Democratic Party (LDP), New Conservative Party, and the New Kōmeitō Party); Japan Enacts Law to Help Fight Terrorism, J. JAPANESE TRADE \& INDUSTRY (Jan./Feb. 2002) (detailing the vote and public support), available at http://www.jef.or.jp/en/jti/200201_004.html. The Japanese text of the Anti-Terrorism Special Measures Law is available at http:// www.kantei.go.jp/jp/kakugikettei/2001/1005terohouan.html (last visited Feb. 22, 2003); a summary in English can be found at The Anti-Terrorism Special Measures Law: Tentative English Summary, http://www.kantei.go.jp/foreign/policy/2001/antiterrorism/1029terohougaiyou_e.html (Oct. 2001).

The JMSDF together with ground and air forces comprise the "Self-Defense Forces" (SDF), Japan's de facto military. See infra notes 65-68 and accompanying text (describing the various forces and legal mechanisms by which they were created). By some accounts, the SDF is the military with the second largest budget in the world. For a breakdown of what the budget supports, see Japan Self Defense Forces (JSDF), Center for Defense Information, at http://www.cdi.org/issues/Asia/japanmil.html (last visited Feb. 23, 2003). The startling fact that Japan spends so much on its military is slightly misleading because the SDF budget is capped in practice at one percent of Japan's GDP. See, for example, Sam Jameson, Japan Not Innately Militaristic, JAPAN TIMES, Aug. 23, 2001, http://www.japantimes.co.jp/cgi-bin/getarticle.pl5?eo20010823sj htm, which explains:

Since the end of World War II, Japan has never spent more than 1.8 percent of its GDP on defense, and that peak came in the 1950s when Japan still had a tiny economy. Even Japanese military experts who want Japan to increase its defense budgets dramatically do not advocate spending more than 1.5 to 1.7 percent of the GDP. And not once since 1986 has the defense budget even reached the limit of 1 percent of the GDP that was supposed to have been lifted in that year.

For the second largest economy in the world, this results in a massive total dollar amount but does not suggest that the SDF is one of the world's largest, or even best equipped, militaries. See James E. Auer, Article 9: Renunciation of War, in JAPANESE CONSTITUTIONAl LAW 69, 83 (Percy R. Luney, Jr. \& Kazuyuki Takahashi eds., 1993) (comparing Japanese and U.S. military capabilities); Robert A. Fisher, The Erosion of Japanese Pacifism: The Constitutionality of the 1997 U.S.Japan Defense Guidelines, 32 CORNELL. INT'L L.J. 393, 401 n.47 (1998) (“[T] he SDF consists of 151,000 ground troops; a maritime force of 43,000 troops and 160 vessels; and an air force of 45,000 troops and 510 planes."); of. Mike M. Mochizuki, Jatan and the Strategic Quadrangle, in THE STRATEGIC QUADRANGLE 107, 120 (Michael Mandelbaum ed., 1995) (“Japan will soon have three times as many destroyer-type surface ships and four times as many $\mathrm{P}$ 3C antisubmarine-warfare aircraft as the U.S. Seventh Fleet. Its tactical fighter planes will number $300 \ldots$, which is comparable to the number of fighter aircraft defending the continental United States.").

Historically speaking, the ships that sailed for Diego Garcia were not technically the first dispatch of the SDF abroad since 1945. In 1991 four SDF minesweepers were sent to the Persian Gulf long after hostilities had ceased in the Gulf War. Auer, supra, at 78-79. Furthermore, in 1950 the Supreme Command for the Allied Powers (SCAP) ordered more than ten times as many minesweepers to the coastal waters of Korea in support of the U.N. action on the peninsula. This dispatch resulted in the sinking of two minesweepers and the death of one Japanese sailor, with injuries to eight others. Id. at 79. I discount both operations, however, because in 1991 the minesweepers were operating pursuant to a U.N. resolution and long after the Persian Gulf could reasonably be described as a "combat zone." Similarly, the 1950 minesweepers were acting under SCAP and U.N. auspices and were not dispatched as the result of an inde- 
JMSDF the ability to provide noncombat support to U.S. forces overseas in the war on terror, including resupply, repair, and search and rescue services." More important from a geopolitical standpoint, however, is that the law coterminously represents a radical departure from the post-World War II status quo in East Asia. The mobilization of the Self-Defense Forces (SDF or Jieitai), including the JMSDF, calls into question the constitutionality of the SDF more clearly than ever before with the possible consequence of a sea change in what is arguably the most important bilateral relationship in the world today: the United States-Japan security alliance.

Japan is unique among the nations of the world in that it constitutionally relinquished its right as a sovereign nation to go to war. ${ }^{4}$ Article 9 of the post-World War II constitution provides:

Aspiring sincerely to an international peace based on justice and order, the Japanese people forever renounce war as a sovereign right of the nation and the threat or use of force as a means of settling international disputes.

In order to accomplish the aim of the preceding paragraph, land, sea, and air forces, as well as other war potential, will never be maintained. The right of belligerency of the state will not be recognized."

While the prohibition on military buildup in Article 9 appears to be explicit, revisionist legislators-upset with what they argue was a constitution "imposed" by General Douglas MacArthur and the Supreme Command for the Allied Powers (SCAP) ${ }^{6}$ and prompted by U.S. offi-

pendent decision of the Japanese government. However, the three ships that sailed on November 9, 2001, were acting on the sole authority of the Japanese Diet in an action not sponsored by the U.N. Therefore, their dispatch may properly be described as the first such deployment since the end of the second World War. In any event, this is the first time Japanese destroyers have engaged in an action abroad.

${ }^{3}$ See The Anti-Terrorism Special Measures Law: Tentative English Summary, supra note $2, \$ \$ 2(2)$ (i), 4 (outlining the activities in which Japanese forces will participate).

${ }^{4}$ For a compelling discussion of the cession of sovereign state authority, see generally Eric S. Wilensky, A Contractarian Critique of the Theory of Auto-Limitation: The Fundamental Law of International Relations, 150 U. PA. L. REV. 2011 (2002).

"KENPO art. 9 (Japan).

${ }^{6}$ See, e.g., H. Fukui, Twenty Years of Revisionism, in THE ConstrTution OF JAPAN: ITS FIRST TWENTY YEARS, 1947-67, at 41 (Dan Fenno Henderson ed., 1968) (discussing a form of revisionism, emotional in nature, rooted in the belief that the "MacArthur Constitution" was forced upon Japan); Yōichi Higuchi, The Constitution and the Emperor System: Is Revisionism Alive?, in JAPANESE CONSTITUTIONAL LAW, supra note 2, at 57, 59 ("[T] $]$ he Constitution was indeed imposed by General MacArthur's team . ..."). But see SHólChI KOSEKI, THE BIRTH OF JAPAN's POSTWAR CONSTITUTION 194-208 (Ray A. Moore trans., 1997) (discussing Japanese efforts to strengthen the prohibition in Article 9); Auer, supra note 2, at 70-74 (discussing the contested origin of Article 9). 
cials caught up in the exigencies of the Cold War ${ }^{7}$-have used an inherent ambiguity in Article 9 to justify the creation of the SDF. ${ }^{8}$ The justification advanced by these legislators for the creation and maintenance of the SDF depends upon a flexible interpretation of "war" as an aggressive act. By establishing a military on the basis of a right to "self-defense," the Japanese Diet has sidestepped the constitution; but this is only logically tenable to the extent that the SDF concerns itself solely with the defense of Japan.

The American framers of the Japanese constitution intended that, like the U.S. Constitution, the document they drafted for Diet approval would be the "supreme law of the nation." To safeguard the constitution's primacy, the framers placed significant hurdles in the path of would-be revisionist legislators. Article 96, in particular, provides that amendments to the constitution may only be made by a twothirds affirmative vote in both houses of the Diet and with ratification by a majority of the electorate." In the post-War Japanese milieu both SCAP and the Diet's own constitutional commission believed that such stringent requirements were necessary to ensure constitutional stability and to prevent a backslide from the newly instituted democratic ideals of the "MacArthur Constitution" to the imperialist ones of the prewar Meiji Constitution." The effect of Article 96 is to make revision of the constitution "'either extremely difficult or next to impos-

${ }^{7}$ There is significant scholarship suggesting that the SDF and its precursor, the National Police Reserve, were the product of American Cold War paranoia. For a précis, see PETER J. Herzog, JAPAN'S PSEUdO-DEMOCRACY 224-31 (1993).

${ }^{8}$ For example, while the second clause of Article 9 provides that "land, sea, and air forces, as well as other war potential, will never be maintained," it does not rule out a defensive capability if the "war" of "war potential" is read as an aggressive conflict or, better yet, belligerence. This is one explanation for the circumlocution that provides the SDF with its name. The creative interpretation of Article 9 also extends to the actual makeup of the SDF. For example, the JMSDF does not maintain an aircraft carrier, the inherent purpose of which is the projection of force. Se Chris Ajemian, The 1997 U.S.Japan Defense Guidelines Under the Japanese Constitution and Their Implications for U.S. Foreign Policy, 7 PAC. RIM L. \& POL'Y J. 323, 327 n.28 (1998) ("[A] fighter jet may have guns, but no bombs.").

"KinPO art. 98 (Japan).

Io Id. at art. 96.

"See Japan's Commission on the Constrtution: ThE Final Report 345-50 (Sch. of Law, Univ. of Wash., Asian Law Series No. 7, John M. Maki trans., 1980) (describing the debate the constitutional commission had in 1946 over the strict language of Article 96 and providing a summary of the major positions). For an overview of the Meiji Constitution's provisions, see Shinichi Fujli, The Essentials of JaPANeSE CONSTITUTIONAL LAW (Univ. Publ'ns of Am. reprint ed. 1979) (n.d.); N. MATSUNAMI, The Japanese Constitution and Politics (Univ. Publ'ns of Am. reprint ed. 1979) (1940). 
sible." ${ }^{\prime 2}$ As a consequence, the Diet avoids the need for revision through use of judicial precedents, administrative practices, and circumlocutions such as that employed to describe the SDF. ${ }^{13}$ Under ordinary conditions these methods afford maximum maneuverability while assuring the Japanese public, as well as Japan's allies and neighbors, that the Diet acts within the scope of its grant of power.

The deployment of JMSDF vessels to the Afghani theater, however, represents a departure from the "self-defense" rhetoric of the SDF's supporters and could be a material breach of the prohibitions embodied in Article 9. While initial public reaction in Japan has strongly favored the Anti-Terrorism Special Measures Law and support of the U.S. war on terror, ${ }^{14}$ Japanese opposition parties, in particular the Japanese Communist Party (JCP), have vociferously objected to what they contend is a "distort[ion of] constitutional

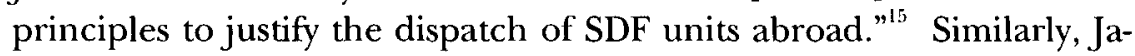
pan's neighbors, long sensitive to the possible reemergence of Japanese militarism, ${ }^{16}$ viewed the dispatch of JMSDF units unfavorably. North Korea, for one, has argued: "This [law allowing SDF participation in the war on terror] indicates that the Japanese reactionaries, who have stepped up their moves for military power and militarization of Japan, took a very dangerous step forward for overseas aggres-

12 JAPAN'S COMmisSion ON THE CONSTITUTION: THE FINAL REPORT, supra note 11 , at 350 (quoting the conclusion of a majority of the commissioners regarding the requirements for amendment). Indeed, according to Lawrence Beer and Hiroshi Itoh, the constitution has never been revised or amended. LAWRENCE W. BEER \& HIROSHI ITOH, THE CONSTITUTIONAL CASE LAW OF JAPAN, 1970 THROUGH 1990, at 12 (1996). at 350 .

1.3 JAPAN'S COMmisSION ON THE CONSTITUTION: THE FINAL REPORT, supra note 11 ,

${ }^{14}$ Two opinion surveys by major Japanese dailies, one by the Mainichi Shimbun and one by the Asahi Shimbun, indicate that a majority of the Japanese electorate supports both the dispatch of the SDF to provide logistical support in the war on terror (sixtythree percent) and the Anti-Terrorism Special Measures Law (fifty-one percent). Yuki Tatsumi, Japan's Homeland Security: Police, or Self-Defense Forces?, Center for Strategic and International Studies, at http://www.csis.org/japan/japanwatch/jw0204.htm (Apr. 26, 2002).

${ }^{15}$ Interview by Hayano Toru with Fuwa Tetsuze, Central Committee Chair, Japanese Communist Party, at http://www.jcp.or.jp/english/jps_weekly/2001_12_fuwa .html (last visited Apr, 30, 2003).

"i See Matthew J. Gilley, Comment, Japan's Developing Military Potential Within the Context of Its Constitutional Renunciation of War, 14 EMORY INT'L L. REV. 1681, 1694 (2000) ("Japan's Asian neighbors . . remain vigilant against the resurgence of a strong Japanese military that could destabilize Asia ... A Article 9 . . offers assurance to these countries that Japan has no intention of revisiting its imperialist past ...."). 
sion ...."17 These nations, together with the opposition parties in Japan, contend that the Anti-Terrorism Special Measures Law is inconsistent with the purposes of Article 9 and even the flexible interpretation of Article 9 used to justify the SDF's existence. ${ }^{18}$ According to a group of Japanese constitutional scholars:

The [law's] intent is to conduct "cooperation and support activities" including supply, repairs, servicing, medical care, and the transport of weapons, ammunition, and personnel, but assuming that the use of force is impossible without such help, this support is an essential part of military action, and is therefore clearly participation in war. This would be the first participation in the use of force by Japan's military apparatus in the postwar years, and would clearly violate Article 9 of Japan's Constitution....

While the potential ramifications of the Anti-Terrorism Special Measures Law for the SDF and Article 9 are serious, the dispatch in November of three JMSDF ships additionally implicates the future bilateral security relationship between Japan and the United States under the U.S.Japan Treaty of Mutual Cooperation and Security. ${ }^{20}$ Based on the terms of this agreement and subsequent implementation "Guidelines," the Japanese and U.S. militaries are pledged to conduct bilateral defense planning and assist each other in the event of an attack on Japan or "a situation in areas surrounding Japan." " In accord with the principles of the constitution, including Article 9, the terms of the Guidelines limit the SDF's contributions to the alliance

${ }^{17}$ N Korea Criticizes Antiterrorism Law, JAPAN TODAY (Nov. 5, 2001), al http:// www.japantoday.com/gidx/news $151666 . h$ tml (quoting an editorial printed in North Korea's official Rodong Sinmun newspaper).

${ }^{18}$ See An Urgent Appeal from Japan's Constitutional Scholars, Japan Computer Access (Oct. 9, 2001), al http://www.jca.apc.org/ kenpoweb/appeal_eng.html (doubting the constitutionality of the Anti-Terrorism Special Measures Law).

${ }^{19}$ Id. Eric Feldman suggested, in a notation to this Comment in draft form, that this group is a leftist organization opposed to the existence of the SDF in principle. I was not able to determine the veracity of his claim.

201) Treaty of Mutual Cooperation and Security, Jan. 19, 1960, U.S.Japan, 11 U.S.T. 1632. This treaty marks an expansion of rights and obligations under the previous security arrangement, signed in 1951, Security Treaty, Sept. 8, 1951, U.S.Japan, 3 U.S.T. 3329.

${ }^{21}$ See, e.g., The Guidelines for U.S.Japan Defense Cooperation, Sept. 23, 1997, 36 I.L.M. 1621 (1997) [hereinafter Guidelines] (constituting a collaborative outline of policies drawn up by the Subcommittee for Defense Cooperation that superceded the previous 1978 guidelines).

${ }^{22}$ Guidelines, supra note 21, at art. V; see also Murata Kōji, Do the New Guidelines Make the Japan-U.S. Alliance More Effective?, in THE JAPAN-U.S. Alliance: NEW CHALlENGES FOR THE 21ST CENTURY 19 (Nishihara Masashi ed., 2000) (discussing the 1997 Guidelines and the United States-Japan alliance in the post-Cold War context). 
for certain actions. In practice, this means the SDF is only committed to providing rear-area support, nonoffensive information gathering, and minesweeping in the event of a conflict outside of Japan. ${ }^{23} \mathrm{Al}-$ though the Anti-Terrorism Special Measures Law meets these limitations, Afghanistan likely does not qualify as an "area surrounding Japan." Japanese participation in the war on terror, at least insofar as it occurs outside the Guidelines' operational area, is therefore an expansion of the SDF's role in the joint security relationship. Furthermore, the use of weapons, albeit strictly confined to cases of selfdefense or necessity, is not as tightly controlled under the AntiTerrorism Special Measures Law as under the previous SDF principle of nonparticipation. ${ }^{25}$ The expanded role of the SDF thus calls into question the existing security arrangement between the United States and Japan, even as it raises the precedent question of whether the SDF and its actions in support of the war on terror are constitutional.

This Comment will assess the Anti-Terrorism Special Measures Law under the strictures of Article 9 and its subsequent interpretation by Japanese courts and the Diet to determine both the constitutionality of the SDF's participation in the war on terror and the probable response of the majority coalition to the arguments of the opposition parties. In addition, the Comment will look to the Treaty of Mutual Cooperation and Security to discern possible implications for the future of the United States-Japan alliance. Toward those ends, Part I considers the circumstances surrounding the adoption of Article 9 and its diachronically asynchronous interpretation from 1947 to the promulgation of the 1997 Guidelines. Part II examines the Guidelines in brief, with particular attention to the role of the SDF in U.S.-

${ }^{23}$ Guidelines, supra note 21, at art. V; see also Michael J. Green, Interests, Asymmetries, and Strategic Choices, in THE U.S.-JAPAN SECURITY ALLIANCE IN THE 21sT CENTURY: PROSPECTS FOR INCREMENTAL CHANGE 1, 8 (1998) (contending that adoption of the Guidelines is predicated on accepting only a limited role of the SDF in "rear-area" cooperation and not pushing for SDF "collective defense" cooperation).

${ }^{24}$ While Article V of the Guidelines declares that "areas surrounding Japan" is not a geographical concept, but rather a situational one, there must still be a geographical construct operating or else better language would likely have been chosen. For a discussion of the geographical/situational contrast, see Murata, supra note 22, at 31-32.

${ }^{25}$ See Diet Passes Antiterrorism Special Measures Law, supra note 2, http:// www.fpcj.jp/e/shiryo/jb/0145.html ("SDF personnel were previously allowed to use their weapons only in self-defense."); see also The Anti-Terrorism Special Measures Law: Tentative English Summary, supra note 2, at art. 12, para. 10 (prohibiting the use of weapons by SDF personnel except in cases of self-defense or necessity when a senior officer so orders, or when "offense or danger to [the] lives and bodies" of SDF personnel or refugees is "too imminent" to wait for permission). 
led military actions (as opposed to search and rescue activities). Parts III, IV, and V address the constitutionality of the Anti-Terrorism Special Measures Law and the subsequent "Basic Plan" implementing the law. Part III provides an analysis of the relevant provisions of the law together with a history of the law's execution and a preliminary sketch of the law's intersection with Article 9. Parts IV and V discuss, respectively, the judicial and legislative responses to the limitations of Article 9 and the continued existence of the SDF. Finally, Part VI presents some possible consequences for Article 9 and the joint security arrangement between the United States and Japan brought on by the Special Measures Law. The Conclusion explores an alternative solution to what the Comment posits may be the ignominious end of the world's sole "peace constitution."

\section{From 1947 TO 1997: FifTY YeARS OF ARTICle 9 EXECESIS}

\section{A. In the Beginning}

The origins of Article 9 are unclear, ${ }^{27}$ but the desire to completely disarm and demilitarize the Japanese archipelago was one of the principle aims of the Occupation. ${ }^{28}$ General MacArthur, who was charged with administering the Occupation through SCAP, sought to establish a "peaceful and responsible government" in Japan that would "respect the rights of other states and ... support the objectives of the United States as reflected in the ideals and principles of the charter of the United Nations." ${ }^{29}$ This goal, MacArthur believed, had two precursive

2is See GLENN D. HOOK \& GAVAN MCCORMACK, JAPAN'S CONTESTEd CONSTTtution: DOCUMENTS AND ANALYSIS 16 (2001) (using the term "peace constitution," discussing the restriction on "war potential," and noting some of the unsuccessful constitutional challenges). While I cite Hook and McCormack for the phrase "peace constitution," the description has been applied by a broad range of scholars to the Japanese constitution because of Article 9. For another example, see Susan V. Thompson, Japan Takes up Arns, MoveOn Peace (July 3, 2002), at http://www.peace.moveon.org/ bulletin36.php3.

${ }^{27}$ There is some dispute over the proper source for the idea behind Article 9. According to Auer, supra note 2, at 71, General MacArthur claimed the idea for a "nowar" clause originated with then Prime Minister Shidehara Kijuro. In contradiction, Shidehara's Foreign Minister Yoshida Shigeru maintained that the idea had been proposed to Shidehara by MacArthur and that the Prime Minister had acquiesced. $I d$.

28 HERZOG, supra note 7, at 218 (citing the "United States Initial Post-Surrender Policy for Japan," approved by President Harry Truman on September 6, 1945). For a good overview of pre-Occupation planning, see HUGH BORTON, AMERICAN Presurkender PlanNing for POSTWAR JAPAN (1967).

${ }^{2 ! 3}$ HERZOG, supra note 7 , at 218. 
components: (1) elimination of any potential for remilitarization of Japanese society; and (2) establishment of a democratic order based on popular sovereignty with a total repudiation of the feudal order that characterized the Meiji state.

To achieve these aims, and to safeguard them in perpetuity, MacArthur advised the Higashikuni cabinet to revise the Meiji Constitution to conform to the goal of the Occupation. ${ }^{31}$ The Shidehara cabinet, which took over the task of constitutional reform from the Higashikuni cabinet, was unable to produce a draft constitution that satisfied MacArthur." MacArthur accordingly ordered SCAP's Government Section to produce a version that contained the components he felt were essential to make Japan a "peaceful and responsible government." Among the points he instructed the Government Section to include was a precursor to Article 9:

"War as a sovereign right of the nation is abolished. Japan renounces it as an instrumentality for settling its disputes and even for preserving its oun security. It relies upon the higher ideals which are now stirring the world for its defense and protection.

31) See Fisher, supra note 2, at 396-97 (commenting on Article 9 and MacArthur's goals for Japanese pacifism and democracy); see also HOOK \& MCCORMACK, supra note 26 , at 5 (analyzing both the conflict and cooperation expressed by a symbolic emperor and democratic ideals).

31 Despite having complete control of Japan during the Occupation pursuant to the Instrument of Surrender, SCAP generally did not directly govern Japanese affairs. Rather, SCAP issued directives to the Japanese government to undertake the actions it desired. These directives were known as "SCAPIN," with "IN" referring to the index number of the directive. BEER \& ITOH, supra note 12, at 3-4; see also Gaimusho tokubelsu shiryobu hen, Nihon senryo oyobi kanri juyo bunshoshu 1-96 (1947) (collecting documents of the Japanese foreign ministry implementing SCAPIN commands). For an explanation of the necessity of constitutional reform, see Dale Sonnerberg \& Donald A. Timm, The Agreement Regarding Status of Foreign Forces in Japan, in THE HANDBOOK OF THE LAW OF VISITING FORCES 379 (Dieter Fleck ed., 2001), which states:

It was hoped that, with this Constitution to define the powers and limits of government and the guidance and oversight of SCAP to help with the transition, the philosophy of Rule of Law would be instilled in the Japanese system, transforming it into something resembling a liberal Western democracy. As the new philosophy took root, the SCAP administration would gradually fade in to the background and ultimately disappear. Id. at 382 .

321 Supreme Commander for the Allied Powers, Pol.tTical Reorientation OF JAPAN, SEPTEMBER 1945 TO SEPTEMBER 1948, at 99 (1949) (criticizing the Shidehara draft, also known as the Matsumoto draft, as "far behind even the most conservative of the unofficial drafts"). 
"No Japanese Army, Navy, or Air Force will ever be authorized and no rights of belligerency will ever be conferred on any Japanese force.,"33

The Government Section's draft that was presented to the Japanese government omitted the "even for preserving its own security" language but otherwise adopted, with slight alterations, MacArthur's point as Article 8 (subsequently renumbered as Article 9). ${ }^{34}$ The Japanese government was reportedly shocked at the breadth of the Article, but felt that there was little they could do to oppose the Occupation's version since MacArthur had personally pushed for its adoption."

Accepting the principle of renouncing war as the sovereign right of the nation and agreeing to the complete and permanent disarmament of Japan, however, were two entirely different things. In both the Privy Council and the House of Representatives, Article 9 (in particular the second paragraph) raised the question of whether the abandonment of "war" should include a concomitant rejection of the right of self-defense. Prime Minister Yoshida Shigeru gave his opinion that the Article 9 concept of "war" embraced both aggressive conflagrations and defensive actions, and he noted that "most modern wars have been waged in the name of the self-defense of States." ${ }^{, 36}$ Conse-

33 OSAMU Nishi, The CONSTITUtion ANd THE NATIONAL DEFENSE LAW SYSTEM IN JAPAN 73 (1987) (emphasis added) (quoting Notes from General MacArthur to Brigadier General Whitney, Chief of the Covernment Section (Feb. 3, 1946)).

${ }^{34}$ See Auer, supra note 2, at 71 (describing the incamations of this Article). According to Auer, the full text of Article 8 read:

[1.] War as a sovereign right of the nation is abolished. The threat or use of force is forever renounced as a means of settling disputes with other nations.

[2.] No army, navy, air force or other war potential will ever be authorized Id. and no rights of belligerency will ever be conferred upon the state.

The "even for preserving its own security" language was apparently deleted by the Government Section because the Section's deputy chief, Col. Charles L. Kades, felt every country was entitled to self-preservation. Id. at 72 (citing NISHI, supra note 33, at $8-9)$.

Cf. id. at 71-72 (describing the Shidehara cabinet's misinformed belief that MacArthur, rather than Shidehara, drafted Article 9). Yoshida's response to questioning by Ambassador Nomura Kichisaburō during the Privy Council debate on the draft indicates the compliant attitude of his government: "Article 9 is the outcome of American apprehension about Japanese rearmament. Consequently it is difficult to revise it." Id. at 72 . Nomura's response is the crux of revisionist attack on Article 9: "'Absolute submission to the Potsdam Declaration requires the disarmament of the Japanese military but does not require a renunciation of armament forever." Id. at 72 73.

3) KOSEKJ, supra note 6, at 193 (quoting Dai 90 kai teikoku gikai shugiin giji sokkiroku, no. 8 , at 123 (June 29,1946$)$ ). 
quently, Yoshida argued, "Maintenance of security has to be through the Occupation Army even when [Japan is] attacked since [Japan is] not allowed [re]armament.",37 Although Yoshida changed his mind on the meaning of "war" by 1954, his interpretation became the official position of the government until the reorganization of the $\mathrm{Na}$ tional Safety Forces (NSF or Hoantai) that created the SDF in $1954 .^{34}$

\section{B. Ambiguities and the Ashida Amendment: The Adoption of Article $9^{3: 5}$}

The Diet's review of the draft constitution prepared by SCAP entailed the creation of a seventy-two-member Special Committee on Revision of the Imperial Constitution in the first post-War House of Representatives (elected April 10, 1946), which received the draft constitution in late June. The Committee was charged with producing an amended draft for Diet approval that would incorporate changes they felt were necessary to "Japanize" the American text." The Committee met in secret from July 25 to August 20 under the chairmanship of the Liberal Party's Ashida Hitoshi, who received SCAP's approval because of his liberal tendencies." Indeed, many of the Committee's proposals, such as adding a House of Councilors to replace the Privy Council (which would vote itself out of existence when it adopted the revised draft), were adopted without SCAP interference. $^{42}$ Nevertheless, it was this Committee and, in particular, Chairman Ashida's revision of Article 9 that would give rise to the ambiguities exploited by revisionist legislators to create and justify the SDF.

37 Auer, supra note 2 , at 72.

${ }^{38}$ KOSEKI, supra note 6 , at 193. Auer states that Yoshida's view became the communis opinio doctorum taught in law schools and universities, and that even junior and senior high school students were taught that "Japan retained a right of national selfdefense in international law [according to the principles of the U.N. Charter], but by virtue of the second paragraph [of Article 9], she could not... maintain an armed force-even for purposes of national self-defense." Auer, supra note 2, at 74 (quoting Kenzō Takayanagi, Some Reminiscences of Japan's Commission on the Constitution, in THE CONSTITUTION OF JAPAN: ITS FIRST TWENTYYEARS, 1947-67, supra note 6, at 71, 86).

${ }^{39}$ As space and time permit only a cursory review of this pivotal constitutional debate, the interested reader is encouraged to attend to the discussion that appears in KOSEKJ, supra note 6, at 192-208, which provides an excellent summary of the Ashida amendment controversy together with relevant quotations from all interested parties.

${ }^{40}$ See id. at 168-69 (describing the process by which the Committee amended the text). The term "Japanize" is used by Koseki to describe Japanese efforts to rein in some of the more egregiously liberal departures from the Meiji Constitution's ideation of rights and relationships in the empire. See id. at 111-40 (comparing the American and Japanese versions of the text).

\footnotetext{
Id. at 170 .

${ }^{42}$ BEER \& ITOH, supra note 12 , at 13.
} 
Ashida's proposed amendment, while largely leaving the language of the SCAP draft intact, made two significant additions. The first change was the semi-rhetorical flourish at the beginning of the first paragraph: "Aspiring sincerely to an international peace based on justice and order ...." This clause apparently was added to divorce the draft of Article 9 from the reality of its composition; that is, as an imposition the Diet was forced to accept because of Japan's military defeat. $^{\text {lt }}$ Whatever its original intent, however, this additional clause fundamentally redirected the thrust of the first paragraph of Article 9 from a per se renunciation of war to a pro forma repudiation of militarism. That is to say that the Committee's language provides a rationale for renouncing war as a sovereign right of the nation and thereby changes the goal of Article 9 to one of fostering "international peace based on justice and order." By itself, the first addition proposed by the Committee was probably not fatal to the pacifist intentions of the SCAP drafters. Taken together with the second addition, however, Article 9 becomes ambiguous.

The second change Ashida proposed was the addition to the beginning of the second paragraph of the clause: "In order to achieve the purpose of the preceding paragraph ...." If one accepts that the "purpose" of the preceding paragraph, by reason of the first addition, was no longer a renunciation of war in all respects, but instead a rejection of war as a policy tool (i.e., as a means of settling international disputes) because "international peace" must be based on "justice and order," then the subsequent declaration that Japan will not maintain "war potential" takes on a different cast. By this interpretation, Article 9 is not absolute in denying the Japanese a military. Instead, the prohibition only reaches "war potential" maintained for offensive purposes; "war potential" is acceptable so long as it is maintained for the purpose of self-defense and not for disturbing international peace. ${ }^{41 i}$

43. KENPO art. 9, para.l (Japan).

${ }^{4}$ KOSEKI, supra note 6, at 194 (citing Committee member Inukai Takeru's explanation of the addition, Kenpō kaisei shoiinkai himitsu gijiroku (Kiyoshi Mori ed., 1983)). If the clause was added to dissuade later critics from arguing that the constitution had been imposed, it has singularly failed to achieve its purpose. Legislators still claim that the 1946 constitution is "MacArthur's Constitution." See sources cited supra note 6 for discussion of MacArthur's influence over the adoption of the constitution.

45. KENPO art. 9, para.2 (Japan).

${ }^{40}$ There is contradictory evidence regarding whether Ashida intended the additions made in committee to encompass such a broad reading. In his book, which ap- 
The rhetorical loophole thus created by the Ashida amendment to Article 9 immediately concerned the Occupation authorities after the Article's approval by the House of Representatives in late August. The Chinese delegation to the Far East Commission (FEC) objected to the implicit "danger" embodied in the Ashida amendment because "if Japan will be allowed to maintain armed forces for other purposes than those enumerated [in Article 9], that means there is [a] possibility for Japan to employ such armed forces under certain pretexts, such as, for instance, self-defense." representatives at the FEC raised similar concerns. ${ }^{48}$ MacArthur apparently agreed with the representatives that the text of Article 9, as amended by Ashida's Committee, "contain[ed] implications which could not be acceptable to [the Occupation]." Yet, in spite of the troubling aspects of the Ashida version, MacArthur believed that additional provisions in the constitution, such as universal suffrage (Article 15) and the requirement that the Prime Minister and all Ministers of State be civilians (Article 66), provided sufficient guarantees that any future rearmament of Japan under Article 9 would be precluded."

peared on November 3, 1946, the same day the new constitution was promulgated, Ashida argued:

The renunciation of war and the threat of use of force in Article 9 refers to a means of resolving an international dispute. If applied to a real case, it would be an aggressive war. Consequently, this provision does not renounce war and the use of force for the purposes of self-defense.

KoSEKI, supra note 6, at 194 (quoting Ashida hitoshi nikki 319 (Shindō Eiichi ed., 1986)). Koseki contends that Ashida's arguments are disingenuous. He avers that the potential for rearmament made possible by the additions was inadvertent ab initio, but that Ashida and most of the Committee realized after the close of the amendment debates that they had stumbled on a loophole that would permit the creation of something like the SDF. See id. at 200 ("[N]ot one member-including Chairman Ashidathought that inserting the words 'in order to accomplish the aim of the previous paragraph' would be sanctioning war in self-defense or sanctioning the maintenance of war potential for the purpose of self-defense.").

${ }^{47}$ Id. at 202 (quoting Transcript of the Twenty-Seventh Meeting of the Far Eastern Commission, Sept. 21, 1946, at 18-19 (National Diet Library, microfiche FEC (A)0085)).

"see id. at 204 (summarizing the British, Canadian, and Australian representatives' reservations about the amendment).

4:! Id. at 206 (quoting Transcript of the Twenty-Eighth Meeting of the Far Eastern Commission, Sept. 25, 1946, at 8-9 (National Diet Library, microfiche FEC (A)0085)).

!n Id. at 205-06. MacArthur may have thought that the Japanese people, having just endured the most horrific war in human history, would be ill-disposed to electing militarists. Furthermore, the requirement that the cabinet officials be civilians, defined as "persons without military service," id. at 205, was no doubt aimed at the particular abuses of the prewar Meiji system, wherein military officers were able to co-opt the institutions of the Diet to militarize the entire nation. 


\section{Birth of the SDF and the U.S.-Japan Security Arrangement}

While the Occupation may have begun with the goal of total disarmament and demilitarization of Japan, by 1950 MacArthur had reason to regret a literal interpretation of Article 9. The outbreak of the Korean War on June 25, 1950, required the transfer of significant numbers of SCAP forces to the Korean peninsula, leaving Japan largely undefended. Perhaps fearful that Japan was proportionately destabilized by the absence of his army, and therefore prone to communist aggression, MacArthur authorized the creation of a 75,000man National Police Reserve (NPR) to safeguard Japanese internal security." In addition, he began to argue that SCAP had never intended the demilitarization of Japan to prevent "'any and all steps for the preservation of the nation.", "Japan as a sovereign nation," it was avowed, "'possessed the inherent right of self-preservation,"” which in SCAP parlance apparently meant Japan had a right to maintain a military for self-defense..$^{53}$ This argument in turn was part of a general diplomatic effort by the United States to obtain a commitment from the Yoshida government to rearm Japan as a bulwark against communism or, in the alternative, send troops to fight in Korea on behalf of the U.N. while wearing U.S. uniforms."

Yoshida resisted American pressure to rearm, positing that, " [T]o maintain war potential, even for the purpose of self-defense, would mean rearmament. This would necessitate revision of the Constitu-

HERZOG, supra note 7, at 224.

52 Auer, supra note 2, at 72 (quoting DOUClAS MACARTHUR, REMINISCENCES 304 (1964)). MacArthur's dubious contention was part of a general "reverse course" in the Occupation, noted by Japanologists. See generally GARY D. ALLINSON, JAPAN'S POSTWAR HISTORY 53-55 (1997) (describing the shift in American policy toward Cermany and Japan "away from punishment toward reconstruction" by 1947 , and stating that "[i]nstead of punishing Japan, SCAP turned to embracing Japan as an ally in its war against communism"). It is worth noting that MacArthur justified the creation of the NPR on self-defense grounds, but did not hesitate to use NPR minesweepers during the Korean War to clear beaches around the peninsula. See supra note 2 and accompanying text (recounting the use of Japanese minesweepers in 1950).

KOSEKI, supra note 6, at 201 (quoting Colonel Charles L. Kades, a member of SCAP's Government Section, who contended that the omission of the "even for preserving its own security" language in the original draft, and the nonobjection of the U.S. representatives in the Occupation to the Ashida amendment were consistent with SCAP's intent not to deny the Japanese government the ability to defend itself against foreign aggression).

See HERzOC, supra note 7, at 224 ("Senator Warren Magnuson introduced a bill which would have authorised the voluntary enlistment of Japanese in the U.S. Forces."); HOOK \& MCCORMACK, supra note 26, at 13 ("Japan was called upon to mobilize a $300,000-$ man army to support the U.S. effort in Korea . . . "). 
tion." "5:5 Revision, Yoshida must have known, would be a Sisyphean task under the stringent requirements of the constitution. ${ }^{56}$ Furthermore, rearmament was hardly a viable economic option for Yoshida's government, which had been struggling to rebuild the Japanese economy and put an end to the shortages that had plagued Japan since the end of the war. ${ }^{57}$ He did, however, ultimately acquiesce in the creation of the NPR, provided that the paramilitary organization excluded purged "professional militarists." In so doing, Yoshida had to create a variety of neologisms to avoid open conflict with Article $9 .^{59} \mathrm{He}$ eventually had to reverse his earlier position and claim that "war potential" maintained for self-defense was not precluded by Article 9, adopting the ex post facto rationale offered by Ashida for the amendment language. ${ }^{\text {i. }}$

The Peace Treaty of San Francisco, ${ }^{\text {(i) }}$ signed on September 8, 1951, brought the Occupation to an end and marked another milestone in the rearmament of Japan. Pursuant to Article 5(c), Japan was permitted to enter into collective security arrangements, ${ }^{\text {i.2 }}$ which Japan's representatives in San Francisco promptly formed with the United States. Signed the same day as the Peace Treaty, the U.S.Japan Security

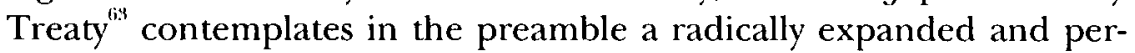
manent role for the NPR:

5s Auer, supra note 2 , at 74.

5ej Supra note 12 and accompanying text (observing the constraints on amendment of the Japanese constitution).

${ }^{57}$ See All.INSON, supra note 52, at 45-82 (describing the post-War Japanese economic condition and SCAP reforms aimed at resuscitating a Japan that had been reduced in the war to yaki-nohara, or "burned plains").

58 HERZOG, supra note 7, at 224. The prohibition against "professional militarists" did not extend to former officers and enlisted men of the Imperial Army below the rank of general, and many found themselves reactivated as members of the NPR. Auer, supra note 2 , at 74

5i) Auer, supra note 2, at 74, gives the example of NPR tanks being relabeled "special vehicles."

10. at 74-75 (positing that "war potential" differed from "defense potential").

(i) Treaty of Peace with Japan, Sept. 8, 1951, 3 U.S.T. 3169, 136 U.N.T.S. 45.

${ }^{62}$ See id. at art. 5(c) ("The Allied Powers for their part recognize that Japan as a sovereign nation possesses the inherent right of individual or collective self-defense referred to in Article $5 \mathrm{l}$ of the Charter of the United Nations and that Japan may voluntarily enter into collective security arrangements."). The right to enter into collective security arrangements may be confused with the right of collective self-defense, which the Japanese government believed was barred by Article 9 (notwithstanding the language referring to "collective self-defense" in the Treaty of Peace with Japan and the U.S.-Japan Security Treaty). For further discussion of this issue, see infra Part III.

${ }^{63}$ Security Treaty, Sept. 8, 1951, U.S.-Japan, 3 U.S.T. 3329. 
The Treaty of Peace recognizes that Japan as a sovereign nation has the right to enter into collective security arrangements, and further, the Charter of the United Nations recognizes that all nations possess an inherent right of individual and collective self-defense.

In exercise of these rights, Japan desires, as a provisional arrangement for its defense, that the United States of America should maintain armed forces of its own in and about Japan so as to deter armed attack upon Japan.

The United States of America, in the interest of peace and security, is presently willing to maintain certain of its armed forces in and about Japan, in the expectation, however, that Japan will itself increasingly assume responsibility for its oun defense against direct and indirect aggression, always avoiding any armament which could be an offensive threat or serve other than to promote peace and security in accordance with the purposes and principles of the United Nations Charter. ${ }^{6.4}$

Accepting this language committed the Yoshida government to a rearmament program and a necessary reorganization and expansion of the NPR, which had heretofore effectively served as an auxiliary to Occupation forces in Japan. The raison d'être for the reorganization is hinted at in the preamble: Japan's military would have to be purely defensive in nature, and therefore of limited capabilities. But the Treaty does not indicate what the boundaries of those capabilities should be. In essence, then, the U.S.-Japan Security Treaty at once reified the Ashida amendment's theoretical exception to Article 9 while making it incumbent upon the Japanese government to actually create a self-defense force.

Following the conclusion of the U.S.-Japan Security Treaty, Japanese rearmament started apace. In 1952, the NPR was combined with a maritime component to form the $\mathrm{NSF}^{65}$ an organization that was "unquestionably military" in character." In 1953, Japan entered into talks with the United States over a plan to incrementally build up its forces in order to achieve the minimum troop levels required by the Mutual Security Assistance program in exchange for economic incentives. ${ }^{67}$ The closing months of 1953 and the first six months of 1954

II. at 3331 (emphasis added).

Auer, supra note 2, at 76. Auer describes this existing maritime component, the Maritime Safety Agency (MSA), as "Japan's coast guard." Id.

ifi HERZOG, supra note 7 , at 226.

it See generally id., at 226-28 (discussing this rapid series of events). The Mutual Security Assistance program required each country seeking economic aid from the United States (in the form of grants, loans, and reduced barriers to trade) to maintain armament sufficient to contribute to the defense of the "Free World." Id. at 227. 
saw yet another iteration of a revived Japanese military, as the NSF combined with a new air-defense component under the auspices of the Defense Agency Establishment Law (Bōeichō Setchi-hō) and the Self-Defense Forces Law (Jieitai-hō) to form the SDF. ${ }^{6 *}$ By 1955, as far as the ruling Liberal Democratic Party (LDP) was concerned, the SDF position vis-à-vis Article 9 was summed up in an official statement: " [T] he case of military power as a means of defending the nation when the nation has been attacked by military power is not counter to the Constitution." “[t] he transition from 'police' to 'army' [was] unmistakable."

In 1960, over domestic protests that would bring down his government, Kishi Nobusuke signed the U.S.-Japan Treaty of Mutual Cooperation and Security and thereby laid the cornerstone for the United States-Japan bilateral relationship. The new treaty was ostensibly a revision of the old U.S.Japan Security Treaty, but in fact it augured a shift to a more equitable relationship between the United States and Japan than had been the case under the 1951 arrangement. For example, while preserving the same quintessential rights and obligations as under the 1951 Treaty, the 1960 agreement qualifies U.S. base rights in Japan and makes mutual consultation a regular feature of the relationship for use of its Japanese bases." Furthermore, pursuant to the Article IV requirement to "consult together from time to time regarding the implementation of this Treaty," the United States and Japan committed themselves to developing a substantive military structure for defense cooperation. ${ }^{72}$ This development has resulted in the periodic issuance of Guidelines to govern their commitment to

lix See Auer, supra note 2, at 76-78 (noting that the NPR formed the basis for the Ground Self-Defense Forces (JGSDF or Rikugun), the MSA, and the JMSDF; and the new air force component became the Air Self-Defense Forces (JASDF or Kutgun)); HERZOG, supra note 7, at 230 (describing the Self-Defense Forces Law as providing "the transition from ... maintaining peace and order within Japan to a force to counter outside aggression").

Auer, supra note 2, at 76 (quoting K. MASUHARA, NiHON NO BOEI 58 (1961)).

7) HERZOG, supra note 7, at 230.

7 See Treaty of Mutual Cooperation and Security, supra note 20, at arts. IV-VI (agreeing that the respective parties will cooperate with each other and that the United States may use bases in Japan). Article IV is indicative of the "mutual" element of the Treaty: "The Parties will consult together from time to time regarding the implementation of this Treaty, and, at the request of either Party, whenever the security of Japan or international peace and security in the Far East is threatened."

See Murata, supra note 22, at 24-32 (discussing bilateral efforts to define the limits of defense cooperation between the U.S. military and the SDF). 
one another under the Treaty. The most recent promulgation of Guidelines occurred in $1997^{73}$

\section{II. “AREAS SURRounding JAPAN": THE SDF AND THE 1997 GUIDELINES}

The 1997 Guidelines were an attempt to redefine the security relationship for a post-Cold War era. With the collapse of the Soviet Union in 1991, the military threat that had long been the sine qua non of the mutual security arrangement disappeared, and analysts on both sides of the Pacific looked for a new ratio vivendi for the United States-Japan alliance. ${ }^{74}$ Due to continuing instability in the Asia-Pacific region, particularly the Korean peninsula and Taiwan, the new direction was to expand upon the original goal of defending Japan from external aggression to include operations aimed at restoring regional stability to "areas surrounding Japan." Morimoto Satoshi, a member of Japan's prestigious Nomura Research Institute, described the 1996 Japan-U.S. Joint Declaration on Security that gave rise to the 1997 Guidelines as "the most significant turning point for the [United States-Japan] alliance since the 1960 Mutual Security Treaty." In fact, the 1997 Guidelines work two even more fundamental changes in the alliance structure than Morimoto could have predicted.

\section{A. Attack on Japan}

The 1997 Guidelines continue to place emphasis on the bilateral commitment to repulse armed aggression against Japan, but reduce the U.S. military's role to support of the SDF, which now has "primary responsibility" for conducting defensive operations. ${ }^{77}$ Previously, the SDF was largely an auxiliary force for the U.S. military's defense of Japan with the narrow obligation of repelling "limited, small-scale ag-

73 See supra note 21 and accompanying text (noting the adoption of the Guidelines for U.S.Japan Defense Cooperation).

${ }^{74}$ See Murata, supra note 22 , at 21 ("[W]ith the ideological conflict of the cold war over, ... the current argument for retaining the alliance has shifted to its multifunctional character.").

75. Guidelines, supra note 21, at art. I.

${ }^{71}$ Satoshi Morimoto, A Tighter Japan-U.S. Alliance Based on Greater Trust, in TOWARD A True AllianCE: Restructuring, U.S.JAPAN SECURIty RElations 137, 137 (Mike M. Mochizuki ed., 1997).

${ }^{77}$ Guidelines, supra note 21 , at art. IV. 
gression."78 The 1997 Guidelines reflect the growing disengagement of the United States from its allies, at least in terms of bearing the financial costs of deployment, and the unwillingness of the United States to lose personnel in a fight it does not start itself. ${ }^{79}$ Without another "superpower" to contend with, the rationale seems to be that the SDF has modernized itself to an extent sufficient to preserve the security of Japan. But increased responsibility of the SDF is nevertheless conditioned on the "limitations of [Japan's] Constitution" (although the Guidelines do not refer to any particular provision). Thus, it is conceivable that the United States may have to intervene militarily in situations when the threat to Japan originates in "areas surrounding Japan" but the SDF potentially would be constitutionally prohibited from acting.

\section{B. The SDF's Role in "Areas SurroundingJapan"}

The 1997 Guidelines move beyond the security of Japan proper by creating a role for the SDF in "areas surrounding Japan." Article V of the Guidelines provides that the term "areas surrounding Japan" is to be defined by the situation, without reference to geography." Included in the definition of "situation" are all events that "will have an important influence on Japan's peace and security." amorphous language is no doubt intended to provide flexibility to the SDF to act in support of the United States should the two Koreas begin another conflict or should China move aggressively to reassert its sovereignty over Taiwan, since either instance would involve the dispatch of U.S. forces to the region and the increased use of Japanese bases. The ambiguity of the phrase, however, leaves the range of cir-

${ }^{78}$ Kōji Murata, Japan's Military Cooperation and Alliances in the Asia-Pacific Region: Guidelines for U.S.-Japan Defense Cooperation, in THE SECURITY ENVIRONMENT IN THE ASIAPACIFIC 52, 55 (Hung-mao Tien \& Tun-jen Cheng eds., 2000).

${ }^{79}$ See Fisher, supra note 2, at 404 (highlighting that the Guidelines reflect "a reduced willingness on the part of the United States to bear the financial and personnel costs of defending its allies, including Japan"). For a provocative introduction to the costs associated with the United States-Japan alliance in Japan, see Michael O'Hanlon, Restmucturing U.S. Forces and Bases in Japan, in TOWARD A TRUE ALL.IANCE: RESTRUCTURING U.S.-JAPAN SECURITY RELATIONS, supra note 76, at 149, 149-78.

${ }^{80}$ Guidelines, supra note 21, at art. II.

8) Id. at art. V.

S2 Id. 
cumstances that justify SDF actions outside the Japanese archipelago uncomfortably open-ended in the eyes of Japan's neighbors. ${ }^{\mathrm{R}}$

Under the Guidelines, the SDF is permitted to take "appropriate measures" in cooperation with the United States to respond to situations in areas surrounding Japan. ${ }^{84}$ These measures are roughly categorized into two groups: (1) cooperative or unilateral actions, initiated by either government; and (2) support for U.S. military operations." The first category comprehends "relief activities and measures to deal with refugees," evacuation of noncombatants to a safe haven, and enforcement of economic sanctions. ${ }^{87}$ This category is comparatively nonproblematic from an Article 9 standpoint since it tracks the "self-defense" conceptualization of the SDF as expressed by Yoshida ${ }^{88}$ and recognized in the 1951 Security Treaty." The only question that would arise in any of these situations is whether the SDF could use force in pursuit of these activities."

"8.3 Fisher, supra note 2, at 405. The Chinese, in particular, were concerned that the Guidelines presented a U.S.-Japanese strategy of containment. It was apparently with their objections in mind that the Guidelines draft committee included the sentence: "The two Covernments will make every effort, including diplomatic efforts, to prevent such situations from occurring." Guidelines, supra note 21, at art. V; see Mike M. Mochizuki, American and Japanese Strategic Debates: The Need for a New Synthesis, in TOWARd a True Alliance: Restructuring U.S.JAPAN SECuRity RElations, supra note 76, at 74-75 (citing China's suspicions of a policy of containment); Murata, supra note 22, at 31 (noting that "China became suspicious about the intentions of the United States and Japan"); see also Ajemian, supra note 8, at 342-48 (arguing that the United States-Japan alliance needs to be revised, but cautioning that "anytime Japan considers changing its passive military role to that of an active role, Japan's neighbors loudly object"). For Korea's reaction, see Fisher, supra note 2, at 407.

Guidelines, supra note 21 , at art. V(2).

si. $I d$.

8li Id. at art. $\mathrm{V}(2)(1)(\mathrm{a})$.

${ }^{87} I d$. at art. $\mathrm{V}(2)(1)(\mathrm{b})-(\mathrm{d})$.

so See discussion supra note 60 and accompanying text (differentiating between "defense potential" and "war potential").

8!) Each of the four activities expressed in Article $V(2)(1)$ are reasonably designed to "promote peace and security in accordance with the purposes and principles of the United Nations Charter." Security Treaty, supra note 63, at 3331.

"See Fisher, supra note 2, at 406 ("The guidelines do not clarify how much force Japan can use in any of these scenarios."). For example, could units of the JASDF shoot down hostile planes while evacuating Japanese nationals from the Korean peninsula? The answer, for Article 9 purposes, would most likely hinge upon whether the hostile planes fired first and whether use of force was absolutely necessary for selfdefense. This approach stands in sharp contrast to that of the international community, which has largely accepted the use of force in these kinds of situations. See generally Thomas C. Wingfield, Forcible Protection of Nationals Abroad, 104 DICK. L. REV. 439 
The second category is far more problematic from an Article 9 standpoint because it permits the SDF to provide rear area support for U.S. combat operations both within Japan proper and "on the high seas and international airspace around Japan." If one accepts the revisionist liberal interpretation of Article 9 that permits the existence of the SDF, one must also accept the corollary that "self-defense" can only mean actions carried out in the Japanese archipelago. Otherwise, as the Chinese delegation to the FEC argued," self-defense is only a pretext for creating "war potential." That potential, deployed abroad, would undermine the concept of "self-defense" because the object of defense would no longer lie within the purview of the deployment. That is, SDF units abroad would conduct their activities under the Guidelines with the immediate goal of effectuating U.S. combat operations. Only proximate advantage inures to Japanese security. Thus the deployment would appear more aggressive than defensive in nature. Under any conventional interpretation, Article 9 stands as an absolute bar to that kind of activity.

If the expanded role of the SDF under the 1997 Guidelines raises a legitimate question about the constitutionality of the United StatesJapan security arrangement, then the Japanese response to the events of September 11, 2001, demands an answer that the Diet and the Japanese court system have heretofore avoided.

\section{The ANTI-TERrorism SPECIAL MEASURES LAW}

On September 12, 2001, Prime Minister Koizumi Junichiro responded to the terrorist attacks in the United States by pledging his government would "spare no effort in providing necessary assistance and cooperation [to the United States]."

(2000) (giving a historical overview of the development of this doctrine and examples of recent evacuations conducted through the use of force).

${ }_{91}$ Cuidelines, supra note 21 , at art. $\mathrm{V}(2)(2)(\mathrm{b})$. In addition to providing rear area support, under the Guidelines Japan is obligated to "conduct such activities as intelligence gathering, surveillance and minesweeping, to protect lives and property and to ensure navigational safety." Id. at art. $\mathrm{V}(2)(3)$. Furthermore, Japan will provide, in case of need, additional temporary facilities for U.S. forces, such as "civilian airports and ports." Id. at art. $\mathrm{V}(2)(2)(\mathrm{a})$.

See supra text accompanying note 47 (noting China's concern that permitting Japan to maintain armed forces raises the possibility that Japan could employ those forces under the pretext of self-defense).

${ }^{93}$ Koizumi Junichiro, Prime Minister of Japan, Statement at Press Conference (Sept. 12, 2001), http://www.kantei.go.jp/foreign/koizumispeech/2001/0912kaiken_ e.html (English translation). 
solved that "Japan [would] take its own initiative towards the eradication of terrorism, in cooperation with the United States," and committed his government to taking measures necessary for the eventual dispatch of SDF units. ${ }^{14}$ Apparently the decision to involve the SDF was prompted by the September 15, 2001, comments of U.S. Deputy Secretary of State Richard Armitage, who bluntly advised the Japanese ambassador in Washington that Japan should "show the flag" in any future military action.":5 Ostensibly bound by Article 9, Koizumi's cabinet then sought to contrive means by which Japan could provide SDF support "within a scope that [did] not constitute an integral part of the use of force." ${ }^{36}$ Their efforts culminated on October 29, 2001, in Diet approval of the Anti-Terrorism Special Measures Law. ${ }^{17}$

The Special Measures Law resembles the 1997 Guidelines in the latitude it grants the SDF to conduct cooperation and support activities with the United States, engage in search and rescue operations, and provide aid (e.g., medical, alimentary) and humanitarian services. ${ }^{1 / 8}$ In addition, the Special Measures Law, like the Guidelines, allows the SDF to provide "supply, transportation, repair and maintenance, medical services, communications, airport and seaport services, and base support" to U.S. forces." The Special Measures Law goes further than the Guidelines, however, by authorizing the SDF to conduct its activities in the territory of foreign countries with the preapproval of the foreign nation, and on the "high seas." ${ }^{100}$ Likewise, the prohibition on the use of force is attenuated:

Members of the Self-Defense Forces ... may proportionately use weapons when an unavoidable and reasonable cause exists for use of weapons to protect lives and bodies of themselves ... or those who are with them

94 Koizumi Junichiro, Prime Minister of Japan, Opening Statement at Press Conference (Sept. 19, 2001), http://www.kantei.go.jp/foreign/koizumispeech/2001/ 0919 sourikaiken_e.html (English translation).

95 Gavan McCormack, Japan's Afghan Expedition, JAPAN WORLD (Nov. 5, 2001), at http://www.iwanami,co.jp/jpworld/text/Afghanexpedition01.html; see also Information Update \#58, Pac. Campaign for Disarmament \& Sec. (Nov. 1, 2001), at http:// www.island.net/ pcdsres/58.html (addressing Armitage's comment).

9. U.Japan Summit Meeting, Prime Minister of Japan \& His Cabinet (Sept. 25, 2001), al http://www.kantei.go.jp/foreign/koizumiphoto/2001/09/25nitibei_e.html.

${ }^{97}$ The Anti-Terrorism Special Measures Law: Tentative English Summary, supra note 2.

${ }^{3} \mathrm{Id}$.

Id. $\$ 4(1)$ (iii).

${ }^{100}$ Id. $\$ 3(3)$. 
on the scene and have come under their control while conducting their duties.

Both the use of force and the expanded operational range of the SDF, even beyond that sanctioned by the ambiguous "areas surrounding Japan" language of the 1997 Guidelines, enable Japan's military to be much more proactive in "defense" than ever before.

The "Basic Plan," required by the Special Measures Law and subsequently issued on November 16,2001, goes into further detail about the implementation of the support services the SDF is to provide to the United States and its allies in the war on terror. ${ }^{102}$ In essence, the Basic Plan delineates the size and composition of the SDF force tasked to Diego Garcia, the areas wherein specific operations may be conducted, and a renewable period for the dispatch of forces. ${ }^{103}$ The Basic Plan is also careful to underscore the Anti-Terrorism Special Measures Law's requirement that all support services of the SDF be made in areas not designated as "combat" zones: "[A]ctivities [shall] be conducted[] in areas where combat is not taking place, nor [is] expected to take place throughout the period during which the activities are conducted, and ... security [shall] be ensured while the activities are conducted."104 The reiteration of this point may have been intended to quell fears that the Special Measures Law went too far in lifting the constitutional restraints on the SDF. For example, the Asahi Shimbun carried an editorial in its October 30, 2001, issue criti-

101 Id. $\$ 10$. Another difference between the 1997 Guidelines and the Special Measures Law is the fact that it answers in the affirmative a question posed supra note 90. Given a situation where hostile planes threaten the evacuation of Japanese nationals, if the JASDF had to fire upon them to protect the evacuation that action would be sanctioned by the Special Measures Law. It is important to note, however, that this is still a limited power. The Special Measures Law stipulates that the use of weapons "shall not cause harm to persons," except in the unique cases of self-defense or necessity. The Anti-Terrorism Special Measures Law: Tentative English Summary, supra note $2, \S$ 10(4). Whether the broad prescription for "appropriate measures" in the 1997 Guidelines was intended to convey a similar right is debatable. It is at least conceivable that the Guidelines convey such a right, but in the Special Measures Law that possibility is foreclosed by section $3(2)$.

${ }^{102}$ An English translation of the Basic Plan Regarding Response Measures Based on the Anti-Terrorism Special Measures Law (Nov. 16, 2001) is available at http:// www.kantei.go.jp/foreign/policy/2001/anti-terrorism/1116keikaku_e.html.

${ }^{103}$ Id. According to section 2(4), the SDF can deploy a maximum of two supply ships and three escorts, six transport aircraft and two multipurpose support aircraft, and "[e]quipment necessary to ensure the security of Self-Defense Forces personnel." Id. $\S 2(4)$ (b) (iii) (2). At any one time, total personnel of the SDF is limited to 1200 persons for the JMSDF and 180 persons for the JASDF. Id. \& 2(4) (a).

${ }^{104} I d . \S 2(3)(\mathrm{e})$. 
cizing the new law as "haphazard" and "rather hasty" for what amounts to "a major change to Japan's security policy."

Whether the Koizumi cabinet thought it could paper over the constitutional cracks in the Special Measures Law by crafting a situation wherein Japanese SDF support could supplement the efforts of Japan's allies in the war on terror without running the risk of the use of weapons is immaterial. The SDF may have been contributing to "endeavors to prevent and eradicate international terrorism in order to ensure the peace and security of the international community including Japan itself," ism is "defensive" is tantamount to claiming that the best defense is a good offense. Koizumi's description of what the JMSDF was engaged in when dispatched to Diego Garcia is more akin to a theory of collective self-defense.

Japan has consistently refused to recognize collective self-defense as permissible under Article 9. ${ }^{107}$ Japan's refusal, on constitutional grounds, to participate in the coalition Gulf War is a prime example of this limited reading of Article 9 at work. ${ }^{108}$ Pressed by the United States to join in the fight to liberate Kuwait, the Diet limited its re-

${ }_{10.5}$ Diet Passes Antiterrorism Special Measures Lazw, supra note 2, http://www.fpcj.jp/e/ 8shiryo/jb/0145.html (quoting the Asahi Shimbun).

${ }^{106}$ Koizumi Junichiro, Prime Minister of Japan, Statement on the Passing of the Anti-Terrorism Special Measures Bill (Oct. 29, 2001), http://www.kantei.go.jp/ foreign/koizumispeech/2001/1029danwa_e.html.

${ }^{87}$ See, e.g., HERzOG, supra note 7, at 231 ("Among the legal fictions invented by the [Japanese] government in connection with the organisation of armed forces was the assertion that the constitution prohibited Japan from sending troops abroad and taking part in collective defense arrangements."); Murata, supra note 22, at 32 ("The right of a collective defense is recognized as indigenous to every sovereignty under the UN Charter, but according to the Japanese government the Japanese Constitution disallows the government from exercising that right."); Akiho Shibata \& Yoshihide Soeya, Legal Framework, in United Nations PeACE-KeEping Operations: a GUide to JAPANESE POLICIES 45, 50 (L. William Heinrich Jr. et al. eds., 1999) ("The government has consistently maintained that Article 9 bars the SDF from joining the armed forces of other nations in the exercise of the right of collective self-defence. It argues that Article 9 permits the exercise of self-defence only to the extent necessary to defend Japanese territory."). In 1954 the Diet passed a nonbinding resolution that prohibited the dispatch of the SDF units abroad. According to Shigeru Kozai, the main motive behind the resolution was to obviate the necessity of sending troops abroad to participate in U.S.-led collective self-defense actions. Shigeru Kozai, UN Peace-Keeping and Japan: Problems and Prospects, in JAPAN ANd International Law 29, 31 (Nisuke Ando ed., 1999).

${ }^{1083}$ See McCormack, supra note 95, at http://www.iwanami.co.jp/jpworld/text/ Afghanexpedition01.html ("Japan was roundly criticized for having done 'too little, too late' because it declined on constitutional grounds to participate in the [Gulf War's] Multinational Force."). 
sponse to the contribution of the staggering sum of thirteen billion dollars. The SDF could not be dispatched, it maintained, because the Self-Defense Forces Law made the defense of Japanese territorial sovereignty the principal task of the SDF..$^{10 !}$ Moreover, "joint military action to defeat, eliminate, and even destroy an aggressor" was facially contrary to the renunciation of belligerency adduced in Article 9, ex proprio vigore, even when such action resulted in the ultimate protection of the state. ${ }^{110}$ The Diet would simply not countenance such a broad reinterpretation of the "self-defense" exception to Article 9. Japanese participation in the Gulf War would therefore be limited to nonoffensive actions, such as bankrolling the coalition's ground war. ${ }^{\prime \prime \prime}$

Without adopting a more liberal interpretation of Article 9 that would permit collective self-defense, ${ }^{112}$ the Special Measures Law and the Basic Plan implementation are likely unconstitutional in the same way that the proposed dispatch of troops to the Gulf would have been. Both measures contemplate circumstances where the SDF would be operating abroad and not in direct defense of the Japanese archipelago. Furthermore, the quintessential Article 9 prohibition against the "threat or use of force as a means of settling international disputes" is probably violated by the authorization for the use of force by the SDF to protect people who have come under their control in the Special Measures Law. "Self-defense" seemingly becomes too adumbrative a concept to meet even liberal interpretations of Article 9 under these measures. Even if the actual conduct of the SDF abroad is limited to the noncombat areas mandated by the Special Measures Law and the Basic Plan, the potential for armed conflict out of necessity alone is likely too great a prospect to satisfy Article 9. Attempts to reduce the possibility of combat are largely meaningless, however, because terror-

109 See HERzoG, supra note 7, at 230 ("The principal task of the Self-Defence Forces is to defend our country against direct and indirect aggression." (quoting article 3, paragraph 1 of the Self-Defense Forces Law)).

${ }^{110}$ Murata, supra note 22, at 32-33.

11) See HERzOG, supra note 7, at 231 (describing this maneuver by Japan as "hypocritical subterfuge").

${ }^{112}$ See, e.g., Murata, supra note 22, at 33 ("Collective defense could instead be understood as referring to the obligation to conduct joint military action to prevent military conflicts and to limit damage should they occur."). Murata suggests that because this ideation of collective self-defense equates with collective crisis management, it would be permissible under the Japanese constitution, which does not mention it. Id. Presumably this argument is based on the theory that expressio unius est exclusio alterius (expression of one thing is the exclusion of another). 
ism is a series of acts without "combat zones," and the enemy "won't be able to tell the difference between 'rear' and 'front." "113

If the 1997 Guidelines can be read as a move toward a more permissive interpretation of Article 9 that includes the right to exercise collective self-defense through the "areas surrounding Japan" provision, then the task of determining the constitutionality of the AntiTerrorism Special Measures Law and the Basic Plan devolves upon Japan's Supreme Court. ${ }^{114}$

\section{The Policy of AVoIdance: ARTICle 9, THE SDF, AND THE JAPANESE JUDICIARY}

In contrast to the U.S. Supreme Court-activist or otherwise-the Japanese Supreme Court has pursued a policy of extreme deference to the legislature in exercising judicial review. ${ }^{115}$ Although it is charged with safeguarding the "constitutional democracy and fundamental rights of the people," the court gives priority to "public peace and order." In part, deference to the legislature is the product of the Japanese Supreme Court's acceptance of the political question doctrine, which holds that all questions of a purely political nature, such as the conclusion of treaties, are within the power of the political department (i.e., Diet and Cabinet) and therefore outside the judicial power. ${ }^{117}$ In addition, the Japanese legal system is structured such that legal trainees who favor government policies "self-select" careers in the judiciary and are advanced through the judicial hierarchy to the extent that they support government preferences in their disposition of cases. ${ }^{118}$ Most cases potentially involving a constitutional question

113 Information Update \#58, supra note 95 (comments of Umebayashi Hiromichi); at http://www.island.net/ pcdsres/58.html.

114 KENPO art. 81 (Japan) ("The Supreme Court is the court of last resort with power to determine the constitutionality of any law, order, regulation or official act.").

115 See generally MikiHisa TAKANo, THE THEORY OF AVOIding DEcision OF CONSTITUTIONAL ISSUES: A COMPARATIVE STUDY OF JUdICIAL SEL.F-RESTRAINT IN AMERICAN COURTS AND JAPANESE COURTS (1992) (criticizing the Japanese Supreme Court's tendency of self-restraint and urging it to take a more activist role).

$116 i$ Id. at 33 .

$117 I d$. at 104-05 ("[T] he courts should admit and respect the determination made by the political department. That is to say, political questions are non-justiciable."); see also Hiroshi ITOH, THE JAPANESE SUPREME COURT: CONSTITUTIONAL POLICIES 159-75 (1989) (discussing the self-restraint of the Japanese Supreme Court).

118 See J. Makk Ramseyer \& Minoru Nakazato, Japanese law: an Economic APPROACH 16-20 (1999) (explaining that the structure of the Japanese judiciary "gives judges an incentive to act in those ways that the people deciding their transfers consider appropriate"); J. MARK RAMSEYER \& FRANCES MCCALl ROSENBLUTH, JAPAN'S 
will therefore be resolved on as narrow grounds as possible to avoid having to answer the constitutional question. ${ }^{119}$ As a result, the Japanese Supreme Court has only rarely invalidated legislative acts on constitutional grounds. $^{120}$

The following series of cases illustrates the court's approach to the SDF, Article 9, and the United States-Japan security relationship. ${ }^{121}$

\section{A. The Sunakawa Case}

In 1959 the Japanese Supreme Court heard the case of Sakata $v$. Japan (Sunakawa). ${ }^{122}$ The suit involved seven villagers of the town of Sunakawa who objected to the proposed expansion of Tachikawa Air Base, a U.S. military facility established pursuant to the 1951 Security Treaty. The villagers destroyed fences and interfered with a survey of the property conducted by the Japanese government. They were arrested for trespassing on a U.S. installation but were acquitted on the grounds that the law under which the arrests were made was nugatory. In a hugely controversial decision, the Tokyo District Court held that the Security Treaty of 1951, the basis for the U.S. presence in Japan, was unconstitutional because it was in effect maintenance of "land,

POLITICAL MARKETPLACE 14 (1993) ("LDP leaders appoint to the apex of the judiciary only those who are politically reliable ...."); see also HIROSHI ODA, JAPANESE LAW 95-99 (1992) (discussing the Japanese judiciary in general terms).

119 TAKANO, supra note 115 , at 47-65 (discussing the adjudicative practice of "case in controversy" self-restraint in the United States and Japan).

120 Id. at 33-34 ("Since the birth of the Supreme Court under the Constitution of Japan in 1946, there have been only three or four cases where the Supreme Court has held legislative statutes or acts of government unconstitutional.").

${ }^{121}$ My summary of each case is drawn from the following sources: HERzOC, supra note 7, at 236-39; Ajemian, supra note 8, at 328-30; Auer, supra note 2, at 80-82; Fisher, supra note 2, at 409-13; Gilley, supra note 16, at 1699-1703. Citation is made where appropriate.

${ }^{122}$ The case is reported at 13 Keishū 3225 (Sup. Ct., G.B., 1959), and reprinted in English translation in 4 JAPANESE ANNUAL OF INTERNATIONAL LAW 103 (1960). The socalled Sunakawa case was not the first to test the legality of the SDF. That distinction belongs to the Eniwa case, Japan \%. Nozaki Bros., which is reported in 9-3 Kakyū keishū 359 (Sapporo Dist. Ct., Mar. 29, 1967). Eniwa involved two dairy farmers in the town of Eniwa, Chitose, Hokkaido, who cut telephone wires leading to an SDF base. The farmers had been disturbed by SDF maneuvers at the base, including the use of explosive devices. They were indicted under the Self-Defense Forces Law, Article 121, which provided punishment for "any person who destroys or damages . . things supplied for defense." See TAKANo, supra note 115, at 47-48 (summarizing Eniwa). In defense of their action, the farmers questioned the constitutionality of the SDF under Article 9. The court found that the phone lines did not constitute "things supplied for defense," and acquitted the farmers without reaching the constitutional question they had raised. Id. at $48-49$. 
sea, and air forces, as well as other war potential," in contravention of Article 9. Upon direct appeal to the Supreme Court, the acquittal was reversed. The court held that self-defense was not denied by Article 9 as a sovereign right of the nation, but avoided answering the question of whether the U.S. presence was legal on the grounds that the issue was "political": "[A]ny legal determination as to whether the content of the [Security Treaty] was constitutional was in many respects inseparably related to the political considerations or discretionary power of the cabinet, which concluded the treaty, and on the part of the Diet which concluded it."

\section{B. The Nike Debacle}

From 1973 to 1982 a case challenging the decision of the Ministry of Agriculture, Forestry, and Fisheries to reclassify part of a forest reserve in order to permit the SDF to build a Nike anti-aircraft missile base near Naganuma, Hokkaido was litigated in the Sapporo District and High Courts, and eventually the Japanese Supreme Court. ${ }^{12.4}$ The plaintiffs, all local residents, argued that they derived direct benefits from the forest reserve, including a supply of irrigation and drinking water and protection from floods. ${ }^{125}$ The reclassification scheme, they alleged, illegally deprived them of those rights. In addition, they contended that the intended use of the reclassified section, to build a Nike base, was per se unconstitutional under Article 9 because it qualified as "war potential." In a surprisingly activist decision, the Sapporo District Court agreed with the plaintiffs. The court held:

Viewed in terms of its organization, scale, equipment and capabilities, the SDF is a military force, since it is clearly "an organization of men and material which has as its purpose combat activity involving physical force against a foreign threat." Accordingly, the Ground, Maritime, and Air SDF correspond to the "war potential" of "land, sea, and air forces," maintenance of which is forbidden by Article 9, [Paragraph] 2, of the Constitution. ${ }^{126}$

123 Gilley, supra note 16, at 1700 (quoting an English translation of Sunakawa provided in Kenneth L. PORT, Comparative LaW: LAW AND The Legal. Process in Japan $107(1996))$.

12.4 The case is Ito v. Minister of Agriculture, Forestry and Fisheries, and is reported in Japanese at 712 Hanke JIHO 24 (Sapporo Dist. Ct., Sept. 7, 1973); 27 Gyósai reishó 1175 (Sapporo High Ct., Aug. 5, 1976); 36 MinsHŨ 1679 (Sup. Ct., Ist Petty Bench, Sept. 9, 1982). For translations of the courts' opinions, with introductory notes, see BlEER \& ITOH, supra note 12, at 83-130.

125 BEER \& ITOH, supra note 12, at 83.

126i ll. at 111 . 
The decision of the Sapporo District Court was immediately appealed and promptly reversed by the Sapporo High Court. On review, the high court found that the benefits lost by reclassification of the forest reserve had been remedied at the time of the Nike base construction. ${ }^{127}$ Because there was no harm to the plaintiffs, their first claim was "not justiciable." ${ }^{128}$ This decision effectively dismissed the claim because it deprived the plaintiffs of standing, but the high court also addressed the district court's finding that the SDF was unconstitutional. After a rather tortured analysis of whether the SDF's purpose was "aggressive," in pertinent part the high court held:

[T] he problem of whether or not the existence, and so on of the SDF conforms to Article 9 of the Constitution is a decision concerning state governance, and as a political act of the Diet and Cabinet would ultimately be entrusted to the political judgment of the entire people. It should not be construed to be a matter that courts are to determine.

The Japanese Supreme Court agreed with the Sapporo High Court, but did not reach the issue of the SDF's constitutionality or consider the "purpose" test applied at the district and high court levels.

\section{The Hyakuri Air Base Case}

In Ishizuka v. Japan, ${ }^{131}$ the SDF began purchasing land in Ibaragi Prefecture to build a JASDF base. Residents in the area opposed the SDF's plan and, in order to stymie it, agreed to purchase land that would be essential to the base's construction and then refuse to sell it to the SDF. One farmer who sold his land to participants in this scheme rescinded his contract of sale when the opposition group failed to make final payment. He then sold the land to the SDF. The first sale, however, had clouded the title to the land and the farmer and the SDF brought suit to have the land registration corrected. ${ }^{132}$ The opposition group raised the constitutionality of the SDF as a defense, arguing that the subsequent purchase was a nullity.

127 Id. at 114.

$12 \%$ ld.

${ }^{124}$ Id. at 122.

13a) See id. at 122-30 (containing a translation of the Japanese Supreme Court's opinion of the case).

${ }^{131}$ The case is reported in 43 MINSHIO 385 (Sup. Ct., 3d Petty Bench, June 20, 1989). A translation of the pertinent parts may be found in BEER \& ITOH, supra note 12, at $130-41$.

132 BEER \& ITOH, supra note 12, at 130-31. 
The Mito District Court disagreed, holding that the SDF could purchase the land. In response to the opposition group's claim that the SDF was unconstitutional, the court invoked the political question doctrine to avoid deciding whether the size, organization, and capabilities of the SDF violated Article $9 .{ }^{193}$ It went further than any previous court, however, in stating that the idea of the SDF, by itself, was constitutional: " [T] he use of the right of self-defense for the purpose of preventing and eliminating armed foreign attacks and for organizing and equipping effective and appropriate defense dispositions in advance does not violate Article 9 of the Constitution." $"$ On appeal, both the Tokyo High Court and the Japanese Supreme Court affirmed the Mito District Court's opinion, but neither court reached the constitutional claims of the opposition group, preferring to categorize the action as merely a contract dispute.

\section{X v. Japan}

The most recent case to invoke Article 9 did not address the SDF directly; rather it attacked the decision by Prime Minister Kaifu Toshiki's cabinet to give thirteen billion dollars to the coalition armies involved in the Gulf War. ${ }^{13 i}$ One thousand sixty-seven citizens filed suit in Tokyo District Court alleging that the government's contribution to a war effort violated their rights as taxpayers. Despite being "flush with money" in 1991, the enormous amount pledged by the Japanese government had required special taxes to raise enough money to cover Japan's contribution. ${ }^{1: 37}$ Article 17 of the constitution gives standing to every citizen who has suffered damage through the illegal acts of a public official. ${ }^{139}$ The plaintiffs claimed that Japan's monetary support of the Gulf War was equivalent to participation in the war and therefore illegal under Article 9. They further claimed

133. Aluer, supra note 2, at 81 .

1:34. Il. (quoting in translation 43 MINSHŌ 385).

135 See Auer, supra note 2, at 82 (noting the courts' conclusions that "Article 9 does not apply directly to private acts"); see also Ajemian, supra note 8, at 330 (same).

13: The case is available at 40 JAPANESE ANN. OF INT'L L. 125 (1997) (reprinting the English translation of the case originally reported in Japanese as 62 H.J. 1579 (Tokyo Dist. Ct., May 10, 1996)). An additional claim challenged the dispatch of JMSDF minesweepers to the region long after hostilities had ended, but as that will be discussed infra Part $V$, the analysis here concentrates solely on the tax claim.

${ }_{137}$ See McCormack, supra note 95, at http://www.iwanami.co.jp/jpworld/text/ Afghanexpedition(1.html (comparing the Kaifu and the Koizumi pledges to support foreign military action).

${ }_{138}$ KENPÓ art. 17 (Japan). 
that they were harmed by the tax levied to underwrite that support. ${ }^{139}$ The Tokyo District Court, perhaps predictably, dismissed the plaintiffs' claims without addressing the underlying constitutional claim in any depth. It held that the right the plaintiffs complained had been infringed - a right to "peaceful existence" on the basis of Article 9was too indefinite to be damaged. ${ }^{140}$ Moreover, the constitutionality of the Kaifu contribution to the Gulf War, the court seemed to suggest, was essentially a political question and therefore subject to a presumption of constitutionality. ${ }^{141}$

Taken together, the string of cases dealing with the SDF, Article 9, and the United States-Japan security relationship suggests that the Japanese Supreme Court, while not taking a clear constitutional stance, recognizes a permissible purpose for the SDF in the defense of Japanese sovereignty. If the court considers the SDF unconstitutional, it certainly has had ample opportunity to so hold. The existence of the SDF is just one consequence of the court's avoidance of definitively deciding the constitutional question.

Continued reliance on the political question doctrine, however, makes discerning the extent of SDF constitutionality extremely difficult, if not impossible. For example, the court in $X \%$. Japan gave the same degree of deference under Article 9 to an international act as the appellate court in the Nike debacle gave to a purely domestic act. $^{142}$ The only attempt at limiting the constitutionality of a putative self-defense force, in the Nike anti-aircraft base case, was the Sapporo High Court's "aggressive purpose" test, which the Japanese Supreme Court did not adopt. ${ }^{143}$ Thus, a further consequence of judicial deference to the political question doctrine is the "unfettered power by the Cabinet and the Diet to determine defense policy."144 Unless the Supreme Court of Japan adopts a less deferential approach to judicial review, it will be left to the Diet to determine the proper role of the SDF, and as a result the Anti-Terrorism Special Measures Law will find its ultimate interpretation there.

139 Gilley, supra note 16 , at $1712-13$.

140 Id. at 1714 .

141 Id.

142 See id. at 1715 ("[T]he opinion in $[X v$. Japan $]$ indicates that Japanese courts will apply the same presumption of validity to the government's international acts that they apply to primarily domestic acts, when international acts are challenged on Article 9 principles.").

14:3 Fisher, supra note 2, at 413-14.

144 Id. at 413 . 


\section{Gai-ATsu: Foreign Pressure ANd Diet Decision Making}

The Japanese Diet, like all representative legislative bodies, comprises individuals seeking reelection. Given this truism, it is somewhat surprising to look at the history of the SDF and the multiple interpretations of Article 9 and realize that at every point in the SDF's evolution, from police force to military, the impetus for change has been Japan's bilateral security partner, the United States. Japanologists refer to this phenomenon as gai-atsu, or "outside pressure," and it is often used as an excuse by the government to justify unpopular domestic and international policies. ${ }^{145}$ Reducing the barriers to foreign market competition at the expense of domestic industry in order to benefit consumers is one example of such outside pressure. ${ }^{14 i}$ Another is the Kishi cabinet's negotiation over the Mutual Cooperation and Security Treaty, which, while popular with U.S. military planners, was wildly unpopular in Japan and sparked riots. ${ }^{147}$ In these situations and others, the Japanese government acquiesced to the will of the United States and, in so doing, ignored the needs of its own domestic agenda.

Outside pressure on the Diet to "show the flag" in the international community had been building in tandem with the stratospheric rise of Japan's economy. In 1991 that pressure prompted Prime Minister Kaifu's reinterpretation of the Self-Defense Forces Law in order to dispatch JMSDF minesweepers to the Persian Gulf, long after hostilities had (essentially) ceased. ${ }^{14}$ The decision proved fractious in Ja-

145. See Jean-Pierre Lehmann, Japanese Attitudes Towards Foreign Policy, in THE Prockss of JAPANESE Foreign POLICY 123, 134 (Richard L. Grant ed., 1997) ("To the extent that public opinion influences Japanese foreign policy at all, it is more likely to be foreign than domestic public opinion.").

${ }^{1+4 i} I d$. at 135 . Although policies that reduce the price of consumer goods would intuitively be popular, reduction or elimination of domestic industries entails workforce reductions and the potential for loss of entire sectors of the domestic economy. These are strong disincentives for the politician seeking reelection, and 1 doubt that any candidate would evince such an improbably insouciant attitude toward domestic industry's concern in the absence of foreign pressure.

${ }^{147}$ See HOOK \& MCCORMACK, supra note 26, at 21 (noting that opinion polls "showed substantial support for either unarmed neutrality or dependence on the UN rather than the security treaty with the US"). For a description of the Kishi government's negotiations with the United States and subsequent downfall, see I.M. DESTLER ET Al., Managing an AllianCE: THE POlitics of U.S.-JAPANESE Relations 12-23 (1976).

14A Article 99 of the Self-Defense Forces Law permits the JMSDF to remove mines from "the sea," but does not define the geographical area therein described. Kaifu argued, successfully as it turned out in the case against him, that this ambiguity allowed the JMSDF to operate both in Japanese territorial and international waters. UNITED 
pan and resulted in litigation, but the court in $X v$. Japan gave Kaifu the benefit of the political question doctrine to uphold the deployment. ${ }^{149}$ The dispatch of minesweepers and the thirteen billion dollar contribution to the coalition effort in the Middle East did little to assuage foreign criticism that Japan had done "too little, too late."150

Foreign criticism of Japan's commitment to the international community during the Gulf War culminated in the 1992 promulgation of the U.N. Peace-Keeping Operations Law. ${ }^{151}$ In consideration of Article 9, the law severely circumscribes the range of activities in which the SDF can take part. In general, these activities are logistical in nature, although with Diet approval they may include monitoring ceasefires; patrolling buffer zones; facilitating the exchange of prisoners of war; and performing weapons inspection, collection, and disposal. ${ }^{152}$ The law also places strict limitations on SDF deployment in foreign countries in the form of five "principles" of participation. Three of the principles are preconditions: (1) a cease-fire must be in place and actively maintained among the host countries; (2) the host countries must consent to the SDF participation; and (3) the United Nations must be impartial in the dispute. Two additional principles are procedural: (4) use of arms is limited to cases of self-defense or necessity and may not be ordered by the United Nations; and (5) in the event of a "suspension or termination" of any of the three preconditions, the SDF's participation ends. ${ }^{153}$ The five principles are geared toward minimizing the possibility that Japanese forces will find themselves in

Nations Peacl-Keeping Operations: A Guide to JaPAnese POliCies, supra note 107, at 51 .

149. See Gilley, supra note 16 , at 1713-14 (noting that while the plaintiffs' right to a peaceful existence can be found in the Japanese constitution, the court found the right ambiguous enough to justify reserving the question of content to the legislative body).

${ }^{150}$ McCormack, supra note 95, at http://www.iwanami.co.jp/jpworld/text/ Afghanexpedition0l.html; see also UNITED NATIONS PEACE-KEEPING OPERATIONS: A GuIDE TO JAPANESE POLICIES, supra note 107, at 19 (noting the strong criticism of Japan's role in the Gulf War by the United States and some European countries).

${ }^{151}$ Kokusai rengō heiwa iji katsudō tō ni iaisumu kyōryoku ni kansum hōritsu (Law Concerning Cooperation for United Nations Peace-Keeping Operations and Other Operations), Act No. 79 of 1992 (Japan), translated in UNITED NATIONS PEACE-KEePING OPERATIONS: A GUIDE TO JAPANESE POLICIES, supra note 107, at annex II.

${ }^{152}$ Gilley, supra note 16 , at 1705.

153 See United nations Peace-Keeping Operations: a Guide to Japanese PoliciEs, supra note 107, at 61-65 (enumerating the "five principles" of Japanese participation). 
a situation that would require the "use or threat of force." ${ }^{154}$ In sum, the law attempts to strike a balance between the SDF's legitimation under Article 9 and the outside pressure to contribute more to the international community.

The U.N. Peace-Keeping Operations Law was passed with little popular support ${ }^{155}$ and against the "fierce opposition" of Japan's opposition parties. ${ }^{156}$ By the time it went into effect, however, a majority of the Japanese public accepted the expanded role of the SDF under the law. ${ }^{157}$ This change of heart suggests that the Diet will not feel constrained by popular opinion to further revise and reorient the SDF's mission from the limited purpose of "self-defense" of the Japanese home islands to the vague "collective self-defense" of international order desired by foreign governments. Even if the public sentiment is accorded weight in the Diet's decision-making process, the polls reflect approval of the existence of the SDF and the LDP's push for SDF international participation. ${ }^{158}$ The main opposition party, the Social Democratic Party of Japan (SDPJ), acknowledged this trend with its announcement in 1994 that it would no longer argue that the SDF and the security arrangement with the United States were unconstitutional, a concession which leaves the JCP and a handful of splinter factions within the L.DP as the sole voices of opposition to the liberal interpretation of Article 9..$^{150}$

15.1 See id. at 51 ("When considering the constitutionality of SDF participation in, or cooperation with, UN peace operations abroad, the key question is whether SDF duties will involve the use or threat of force.").

15.5 See HOOK \& MCCORMACK, supra note 26, at 32 (positing that popular support for the law before its adoption was no higher than $36 \%$ of those polled).

Hisashi Owada, Remarks at the 90th Annual Meeting of the American Society of International Law (Mar. 27, 1996), in 90 AM. SOC'Y INT'L. L. ProC. 42, 43 (1996).

${ }_{157}$ See HOOK \& MCCORMACK, supra note 26 , at 32 (stating that popular support for the law had risen to $52 \%$ after the first dispatch of JGSDF troops Cambodia in 1992). The Japanese public may have been prepared to accept an expanded role for the SDF in any event. See EDWARD J. LinCOLn, JAPAN's New Global. ROLE 264 (1993) (citing a poll by Nihon Keizai Shimbun, which found that $70 \%$ of Japanese surveyed before the Gulf War supported SDF participation in international humanitarian work).

${ }^{1: M}$ Cf. HOOK \& MCCORMACK, supra note 26, at 32 (observing that up to $70 \%$ of the public supports revision of the constitution to clarify the role of the SDF); Mike M. Mochizuki, A New Bargain for a Stronger Allance, in TOWARD a True Ald.tAnce: RESTRUCTURING U.S.-JAPAN SECURITY RELATIONS, supra note 76, at 5, 33 (noting that $33.4 \%$ of Diet members support the move toward greater military cooperation with the United States).

15:? See HOOK \& MCCORMACK, supra note 26, at 29-30 (describing the dramatic compromise by the SDPJ). 
In the wake of the September 11 terrorist attacks, public approval of a more active role for the SDF has become even more pronounced in opinion polls. According to surveys conducted by the Asahi Shimbun and the Mainichi Shimbun, between fifty-one and fifty-seven percent of respondents favored the dispatch of JMSDF units called for by the Anti-Terrorism Special Measures Law, with seventy-one percent in support of closer cooperation with the United States in antiterrorism measures. ${ }^{160}$ With the confluence of gai-atsu to join the war on terror and significant domestic approval supporting the Anti-Terrorism Special Measures Law and the Basic Plan, it is therefore unlikely that the Diet will do more than nominally observe the strictures of Article 9, as in the U.N. Peace-Keeping Operations Law. Without the check of judicial review, the SDF, itself a product of outside pressure, will probably continue its progression from a "self-defense" force to a fullfledged military under the new measures, irrespective of Article 9.

\section{DE JURE CONSTITUTIONALITY OF THE ANTI-TERRORISM SPECIAL. MEASURES LAW: IMPLICATIONS FOR ARTICLE 9 AND THE U.S.-JAPAN SECURITY ARRANGEMENT}

\section{A. The Future of Article 9}

The Anti-Terrorism Special Measures Law invests the SDF with the responsibility of carrying Japan's burden of collective self-defense. Although the law was carefully tailored by the Koizumi cabinet to avoid overt deviation from Article 9, the reality is that the expanded operational abilities, both geographic and military, materially diverge from the spirit of the "no war" clause. The limited exception to Article 9 has recognized a place for "self-defense," but the Japanese government has long argued that the exception, together with the right of collective self-defense, is confined to a protective force operating in the Japanese archipelago that can use its weapons only when fired upon. The Japanese judiciary has deferred the question of the constitutionality of this exception to the Japanese legislature. The Diet should therefore take steps to clarify the SDF position under Article 9 . This is especially important when, as in the case of the Special Measures Law, the Diet has fundamentally altered the purpose of the SDF.

There are three possible courses that government action may take: (1) repeal Article 9; (2) amend Article 9 to reflect the Diet's liberal

\footnotetext{
${ }^{160}$ McCormack, supra note 95, at http://www.iwanami.co.jp/jpworld/text/ Afghanexpedition01.html.
} 
interpretation of the language justifying the existence of the SDF and the concept of collective self-defense; or (3) continue to read into the ambiguities introduced by the Ashida Amendment the desired defense policy without changing the constitution. Of these three approaches, only the first two provide any clarification of the SDF's constitutional position. The first course of action would make the SDF legal without qualification, but it is extremely unlikely since a majority of the Japanese people support the ideal expressed in Article 9 and feel it is an important part of the Japanese national identity. ${ }^{161}$ Furthermore, repeal would require a two-thirds majority in each house of the Diet and the support of a national referendum, both of which present bars much too high for the government to overcome.

The second course, by way of contrast, is much more likely because Japanese public sentiment is for the first time beginning to favor revision of the constitution, including Article 9, with clarification of the SDF's role as a major goal. ${ }^{1.2}$ With little opposition remaining in the Diet to the expanded role of the SDF under the U.N. PeaceKeeping Operations Law, the 1997 Guidelines, and the AntiTerrorism Special Measures Law, the conditions are ripe for proposing an amendment that will maintain the spirit of the prohibition against "war" while recognizing the right of the Japanese to have a military that can take part in collective self-defense actions. This is especially true given the overwhelming support of the populace for SDF participation in the war on terror. ${ }^{163}$ Although amendment would by no means be assured, approximately ninety percent of the Japanese people support the SDF and an expanded role for Japanese forces abroad, ${ }^{\text {lit }}$ suggesting that the probability of amendment is higher now than it has ever been before.

The third course of action the Diet might take is to continue redefining the "self-defense" exception to Article 9 without modifying the constitution. This method is plainly unacceptable from an international standpoint. In the international arena, Article 9 has acted as a

Itil See Fisher, supra note 2, at 415 (“[T] he Japanese people today embrace pacifism as part of their national identity... Thus, despite the problems of living with Article 9, the Japanese people are generally committed to its preservation.").

${ }^{1 \text { li2 }}$ See HOOK \& MCCORMACK, supra note 26 , at 32 (explaining that the majority of those people polled supported constitutional revision in large part to make an international contribution).

${ }_{1633}$ See McCormack, supra note 95, at http://www.iwanami.co.jp/jpworld/text/ Afghanexpedition01.html (reporting the increase in public support for SDF participation following the September 11, 2001, terrorist attacks).

Itis Auer, supra note 2, at 83. 
safety device to forestall the full remilitarization of Japan, a prospect that provokes anxiety in Japan's neighbors. ${ }^{165}$ To continue to expand the "self-defense" exception without changing the constitution "hollows out" the prohibition and makes the promise of an eternal renunciation of war an empty one. ${ }^{\text {liti }}$ Clarification is absolutely essential in this situation, lest the ever-expanding definition of "self-defense" one day encompass the pretext for war about which the Chinese delegation to the FEC complained. ${ }^{\text {liz }}$ In addition, the vaguely defined operational capabilities of the SDF under Article 9 provide an "out" for a Japanese cabinet to avoid international commitments it might otherwise have been obligated to fulfill-for example the refusal to send SDF units to join the coalition army in the Gulf War. The international community needs to be convinced that Japan, as the world's second largest economy, will be an active part of global action aimed at the preservation of peace and order, rather than a passive observer and beneficiary.

The Japanese government has been sensitive to criticism that it has been a "free rider" in international affairs, and has taken steps to remedy the problem with the U.N. Peace-Keeping Operations Law and the Anti-Terrorism Special Measures Law. ${ }^{168}$ Revision of the constitution is an explosively divisive issue, however, and the government may not seek to amend or repeal Article 9 for that reason. Whatever course of action the government takes, the end result is that the Article 9 "no war" provision will no longer stand as an absolute bar to military action, nor as an inherent limitation on the SDF's role in collective self-defense arrangements. In this regard, the Anti-Terrorism Special Measures Law model represents the future.

165. Supra note 16 and accompanying text.

1606 See HOOK \& MCCORMACK, supra note 26, at 17, 21 (discussing the expansion of military capability almost immediately after the inception of Article 9, and how SDF activities "hollow[] out" the article).

${ }^{167}$ Ian Buruma cites this as a rationale for revision of the constitution. Mr. Buruma's reasoning is persuasive, particularly with regard to the nexus between Article 9 and the denial of war guilt by Japanese revisionists. See Ian Buruma, Perilous Underside of Japan's Pacifism, L.A. TIMES, Jan. 21, 2003, at B11 ("[S] olving the [Article 9] issue would rob the revanchist right wing of its argument for denying Japan's belligerent past .... The alternative [is] for the Japanese to rearm-and possibly go nuclear-in a fit of panic, without proper debate or democratic checks and balances.").

tis See supra Part V (detailing Japan's efforts to contribute to international collective support). 


\section{B. The Future of the U.S.Japan Security Arrangement}

The Anti-Terrorism Special Measures Law will likely strengthen the United States-Japan alliance in the twenty-first century, at least for the law's two-year duration. An SDF with expanded operational capabilities will be able to augment U.S. military actions in the Asia-Pacific theater and in the war on terror more effectively through the provision of important rear area support. Furthermore, by committing itself to providing contemporaneous material support to U.S. forces rather than a contribution to the U.S. war chest, the Japanese Diet has made the SDF an integral part of U.S. strategic planning. Japanese cooperation with the U.S. military reaffirms the reciprocal spirit of the 1960 Mutual Cooperation and Security Treaty and elevates Japan from the role of junior partner in the relationship.

A necessary consequence of Japan's expanded participation in the security arrangement will be the correspondingly increased influence Japanese strategists and legislators will have over U.S. policy in the Asia-Pacific theater. The 1997 Guidelines were aimed at increasing the level of coordination on policy issues between the two nations as the alliance shifted its meaning in the post-Cold War world. In practice, the obligation to consult the Japanese on policy decisions has not been fulfilled by the United States. One recent example is the decision by President Bush to include North Korea in the "Axis of Evil," a designation that came as a shock to Japanese legislators looking to normalize relations with that country. ${ }^{169}$ With a greater stake in the collective defense of peace in "areas surrounding Japan," however, Japan ensures that Washington will pay closer attention to the opinions and policy goals of its ally.

The expanded role that the SDF will play in the alliance will also force the United States to rethink its security arrangements with other countries in the Asia-Pacific region. For example, were war to break out on the Korean peninsula, the United States would be obligated to intervene on behalf of its allies in the South. The Japanese would also participate in the conflict by virtue of the probable use of Japanese bases by the United States in prosecuting its intervention and the "areas surrounding Japan" provisions of the 1997 Guidelines. If the AntiTerrorism Special Measures Law is a model for the operational pa-

${ }^{\prime \prime i s ~ S e e, ~ e . g ., ~ K o i z u m i ' s ~ P y o n g y a n g ~ V i s i t ~ a ~ R i s k y ~ B u s i n e s s, ~ A S I A ~ T I M E s, ~ S e p t . ~ 13, ~} 2002$ ("North Korea's inclusion by Washington in ... the 'axis of evil' does not help relations [between Japan and North Korea.]"), http://www.atimes.com/atimes/Japan/ DI13Dh03.html. 
rameters of SDF support, the Japanese may find themselves in situations in which they are forced to fire upon North Koreans. One can easily imagine a scenario wherein a Japanese minesweeper is tasked to Inchon harbor, only to be attacked by elements of the North Korean navy. Under these circumstances the Anti-Terrorism Special Measures Law would permit the JMSDF to return fire and thereby broaden the conflict. South Korea undoubtedly has no interest in witnessing Japanese military intervention on the peninsula and will object to the SDF presence. For that reason the United States must walk a fine line between encouraging the expanded capabilities of the SDF and preventing their deployment in areas that would impair Washington's relationships with third-party nations.

\section{CONCLUSION}

There is every reason to expect that the Anti-Terrorism Special Measures Law represents the future of Japan's international military cooperation. With the dispatch of three ships to Diego Garcia, the Diet continued the policy of reinterpretation of Article 9 and the proper role of the SDF in the post-Cold War security environment. Foreign pressure, popular support, and a judiciary that has left the constitutionality of the SDF and its purposes under Article 9 to the Diet and Cabinet ensure that Japanese legislators will be able to continually reinterpret the SDF's mission in the years to come. Yet, as the SDF increasingly takes on responsibilities that cannot be squared with the concept of "self-defense," the Diet will be forced to confront the inherent inconsistency of a military in a nominally pacifist state.

The Anti-Terrorism Special Measures Law is a challenge to the Diet to either revise the Japanese constitution or scale back the scope of SDF capabilities. Amendment of Article 9 would be an ignominious end for the world's only "peace constitution," even if the revision merely clarified the role of the SDF at home and abroad. Nevertheless, Japan exists among a community of nations and has obligations to the world beyond the maintenance of its pacifist ideal. Japan risks the condemnation of the free world when it conducts "checkbook diplomacy," as in the Gulf War. Furthermore, Japan's pockets are no longer as deep as they were in 1991. The SDF should participate in collective actions designed to improve an international peace based on justice and order. That idea is consistent with the aspiration of Article 9 , and provides the premise for a future Article 9 that legitimates the SDF while continuing to renounce aggressive war. The tough choice between these alternatives is unenviable, but Japanese legisla- 
tors absolutely must make the choice if Japan is to become a "normal" nation. ${ }^{170}$

170 The term "normal nation" as used here was first employed by Ozawa Ichiro to describe the kind of state that he believed Japan must aspire to become through constitutional revision. The hallmark traits of the "normal nation" according to Ozawa are: (1) a willingness to shoulder responsibilities regarded as natural in the international community, irrespective of domestic political difficulties; and (2) cooperation with the international community in remedying worldwide problems affecting the stability of the lives of its people, such as pollution. ICHIRO OZAWA, BLUEPRINT FOR A NEW JAPAN: THE RETHINkING OF A NATION 94-95 (1994). The term is sufficiently broad to encompass the kind of change this Comment contemplates. 